\title{
Yükseköğretim Kurumlarında Türk Halk Müziği Toplu İcra Eğitimi Uygulamalarının ve Karşılaşılan Problemlerin Eğitmen Görüşleri Doğrultusunda İncelenmesi
}

\author{
An Analysis of the Educational Practices of Turkish Folk Music Collective Performance and Faced \\ Problems Based on Educators' Views
}

\author{
Sinan Ayyıldız ${ }^{*}$ - Eren Can Y1ldı**
}

\begin{abstract}
Turkish folk music ensemble courses, as well as individual courses, were adopted as an important method of folk music education in Turkey. The course catalogs of higher music education institutions involve Turkish folk music ensemble courses under various names. Regional collective performance styles, collective performance style of state-controlled institutions and other original ensemble studies with various understandings stand out as factors affecting the content of Turkish folk music collective education offered in these educational institutions. Today, this study was needed to understand how Turkish folk music collective performance education is performed, under which factors, on which preferences and to identify the problems faced by the instructors during the training process. In this research, Turkish folk music collective performance education has been analyzed in higher music education institutions (conservatories and performing arts faculties) in Turkey. We report data from one questionnaire gathered from 24 folk music educators from 16 universities, (15 state universities, 1 private university). As a result of the questionnaire administered to the participants, their application method and the content of the courses focused on Turkish folk music ensemble, the problems faced by the participants in the application and their possible reasons, assessments of participants about these courses, and their opinions about how should be an ideal Turkish folk music collective performance education were determined.
\end{abstract}

\section{Structured Abstract: Introduction, Problem Status and Purpose of the Study}

Turkish folk music ensemble courses, as well as individual courses, were adopted as an important method of folk music education in Turkey. The course catalogs of higher music education institutions involve Turkish folk music ensemble courses under various names. Local collective performance styles, collective performance style of state-controlled institutions and other original ensemble studies with various understandings stand out as factors affecting the content of Turkish folk music collective performance education offered in these educational institutions. Today, this study was needed to understand how Turkish

\footnotetext{
* Dr. Öğr. Üyesi, Ankara Müzik ve Güzel Sanatlar Üniversitesi, İcra Sanatları Fakültesi, Çalgı Eğitimi Bölümü Asst. Prof. Dr. Ankara Music and Fine Arts University, Faculty of Performing Arts, Department of Instrument Teaching ORCID 0000-0001-5472-1899 sinanayyildiz@mgu.edu.tr

** Doktora Öğrencisi, Gazi Üniversitesi, Gazi Eğitim Fakültesi, Güzel Sanatlar Eğitimi Bölümü PhD Student, Gazi University, Gazi Faculty of Education, Department of Fine Arts Education ORCID 0000-0002-7241-1293

eren.c.yildiz@gmail.com

Cite as/ Atıf: Ayyıldız, S., Yıldız, E.C. (2020). Yükseköğretim kurumlarında Türk Halk Müziği toplu icra eğitimi uygulamalarının ve karşılaşılan problemlerin eğitmen görüşleri doğrultusunda incelenmesi, Turkish Studies Education, 15(4), 2443-2466. https://dx.doi.org/10.47423/TurkishStudies.43433

Received/Geliș: 07 May/Mayıs 2020

Accepted/Kabul: 26 June/Haziran 2020

Copyright $($ INTAC LTD, Turkey
} 
folk music collective performance education is performed, under which factors, on which preferences and to identify the problems faced by the instructors during the training process.

Problem status of the research is "How is Turkish folk music collective performance education applied in higher education institutions and what are the problems encountered in practice?" In this direction, problems encountered in the Turkish Folk Music ensemble courses, training process, educational methods and tools, were examined in accordance with the opinions of educators. The ultimate aim of this research is to make suggestions for the solution of the problems that arise in the context of "Turkish folk music collective performance education" and what kind of research should be done. The methodology of the research and the topics discussed were explained in detail in the study, and the findings were interpreted through tables and graphs. In the conclusion part of the research, the obtained data is given and suggestions on the topic are made.

\section{Conceptual / Theoretical Framework:}

It affects the manner in which the Turkish Folk Music collective performance education in Turkey are considered to be three separate elements. These are: "local collective performance style" coming from the tradition of musical meetings, state supported institutional performance style, which was formerly formed as a "radio style" shaped with the formation of the radio, and especially the "modernist folk music ensembles" that can be characterized with "homophonic/polyphonic texture", which have been increasing in number in the last 40-50 years. It is necessary to measure how effective these factors are in education, what kind of problems arise in today's ensemble performance education shaped by the effect of these factors, and how collective performance education is performed.

\section{Method:}

In this study, Turkish folk music collective performance education has been analyzed in higher music education institutions (conservatories and performing arts faculties) in Turkey. We report data from one questionnaire gathered from 24 folk music educators from 16 universities, (15 state universities, 1 private university). As a result of the questionnaire administered to the participants, their application method and the content of the courses focused Turkish folk music ensemble, the problems faced by the participants in the application and their possible reasons, assessments of participants about these courses, and their opinions about how should be an ideal Turkish folk music ensemble education were determined.

In this study, the data required for the research within the survey method was obtained through the interview form structured online via Google Forms and the Likert scale (No, Rarely, Medium Frequency, Generally, Very Frequent) indicating the frequency. Findings found through the interview form were interpreted using qualitative and quantitative data analysis methods. The data obtained through the Likert scale, which indicates frequency, were both interpreted as frequency (n) and percentage (\%) and based on the data obtained from the weighted average of the data. Percentage numerical values produced, based on the obtained data, are rounded to be one digit after the comma. The percentage values of the answers given to the choices of the questions were multiplied by 0 for "none", 0.25 for "rarely", 0.5 for "medium", usually 0.75 for "frequently", and 1 for "very often".

In the process of designing the survey questions, answers to the problem status of the research were tried to be sought. Questions were designed to determine the possible effect on "folk ensemble styles" in education. While designing these questions, the "ensemble models", "musical texture features" and "preferences of instruments", "number of instruments", "preferences of tuning systems" were focused. Also, questions have been designed for the extent to which potential educational materials to be needed in collective performance education. In addition, questions about the problems encountered in the education of Turkish folk music ensemble courses and their frequency of occurrence were generated. It was also necessary to design different questions in order to determine thoughts about the course, the method of the course, the weight of the course in the curriculum and what weight should be. Open-ended "other (please specify)" option has been added to the questions that offer options. The data obtained by the research method of this study were prepared in accordance with the principles of research and publication ethics.

\section{Data Collection and Analysis / Data Analysis}

In the research, literature search was made and the studies that will be the source of this research were determined and examined. Communication was provided through the Google Forms internet survey system 
with predefined field experts, and answers were received to questions related to the subject. Interview data were then analyzed by qualitative and quantitative research methods, aiming to reach results.

\section{Results}

In the light of the data obtained in this study, there are many different problems in Turkish folk music collective performance education and it was seen that there is no education model specific to Turkish folk music collective education and education is carried out with inadequate educational models. It has been determined that the contribution of collective performance to individual performance education is considered to be at a significant level in many different dimensions, and different problems are encountered during collective performance education, especially the lack of a general education model for Turkish folk music collective performance. Most of the participants (Weighted average 82.1\%) stated that they faced problems due to the lack of educational method. While $91.7 \%(n=22)$ of the participants mentioned they train the monophonic songs in the course, 62.5\% $(n=15)$ include multi-party studies. It is seen that Turkish Radio and Television Institution (TRT) Turkish folk music repertoire is highly preferred as a repertoire in monophonic collective performances of Turkish folk music. The problems arising from the scores that do not reflect the real performance of pieces are seen as the biggest problem (Weighted average 88.1\%). It has been determined that traditional folk performance styles, which are among the factors affecting Turkish folk music collective performance education, are highly valued in collective performance education, but there is not enough research done to evaluate local collective performance qualities in terms of music. An important education method in the content of collective performance education of Turkish folk music is based on multi-part folk music. It is observed that the educational materials for multi-part performance are prepared by the instructors who give the lessons in the courses. Most of the participants (Weighted average 70.2\%) stated that they faced problems due to the lack of multi-part Turkish folk music arrangements. It is observed that many problems, especially ornament, nuance, intonation and synchronization problems, were encountered in the collective performance studies. Most of the participants (Weighted average 86.9\%) stated that they faced problems due to the lack of educational material for students at different levels. In line with the data obtained, it was determined that two, three, four-person small instrument groups constitute an important place in the course of the lesson. When the structure of these small instrument ensembles is analyzed, it is seen that the ensemble consist of mostly instruments from saz/bağlama family, and in some cases, group is formed by the accompaniment of the saz/bağlama group with a string instrument, a wind instrument or a percussion instrument. In ensembles consisting from only sazes/bağlamas, between 3 and 6 performers are preferred in education. It was determined that educators prefer "bozuk düzen" and the "bağlama düzeni" as tuning system for saz/bağlama family in ensembles. The majority of the participants stated that the most ideal orchestra was between 4-8 people in order to provide an efficient education, and it was observed that the orchestra more than 14 people were generally not preferred. It is observed that the Turkish folk music collective performance courses are mostly carried out 2 hours or 4 hours a week. The majority of the educators stated that it would be more appropriate for the education to be structured at least 3-4 hours a week.

Keywords: Music Education, Turkish Folk Music Education, Group Music Performance, Instrumental Ensemble, Ensemble Playing

Öz: Türk Halk Müziği eğitiminde toplu icra eğitimi, bireysel çalg1 eğitimin yanı sıra önemli bir müzik eğitim yöntemi olarak benimsenmiş ve çeşitli ders isimleri altında müzik eğitimi veren yükseköğretim kurumlarının müfredatlarına dahil olmuştur. Yerel toplu icra gelenekleri, devlet kurumları çatısı altında çalışan Türk halk müziği topluluklarının toplu icra üslupları ve çeşitli anlayışlarla yapılan özgün topluluk çalışmaları, bu eğitim kurumlarında verilen Türk halk müziği toplu icra eğitiminin içeriğini etkileyen faktörler olarak öne çıkmaktadır. Günümüzde, Türk halk müziği toplu icra eğitiminin nasıl, hangi yöntemlerle, hangi faktörlerin etkisi altında, ne gibi tercihlere dayanarak yapıldığının anlaşılabilmesi ve eğitimcilerin eğitim esnasında ders işleyişine yönelik olarak karşılaştıkları problemlerin tespiti amacıyla bu çalışmanın yapılmasına ihtiyaç duyulmuştur. Bu araştırmada, Türkiye'de misyonu sanatçı yetiştirmek olan yükseköğretim kurumlarında, Türk halk müziği kapsamında toplu icra eğitimi irdelenmiş, akabinde Türkiye'nin farklı bölgelerinde yer alan 15 Devlet, 1 vakıf üniversitesinin ilgili bölümlerinde Türk halk müziği toplu icra derslerine giren 24 öğretim elemanıyla dijital platform (Google Forms) anket sistemi üzerinden birtakım sorulara cevaplar aranmıştır. Öğretim elemanlarına yöneltilen sorular sonucunda toplu icra derslerinin uygulanma biçimleri ve ders içeriklerine, uygulama içerisinde öğretim elemanlarının karşılaştıkları problemlere ve nedenlerine, toplu icra 
hakkındaki durum değerlendirmelerine ve dersin nasıl işlenmesi gerektiğine dair görüşleri tespit edilmiş, konuya ilişkin bazı yorum ve öneriler yapılmıştır. Bilimsel araştırmalarda olması gereken etik kurul izni sebebiyle bu araştırma ve verileri Ankara Müzik ve Güzel Sanatlar Üniversitesi Rektörlüğü Etik Kurulunca 23.07.2020 tarihinde incelenmiş ve araştırmada herhangi bir etik ihlali rastlanmamıştır. Araştırmanın etik onay belgesi 59749768-050.01.04-E.1400 sayı numaralı evrak ile yazarlara tebliğ edilmiştir.

Anahtar Kelimeler: Müzik Eğitimi, Türk Halk Müziği Eğitimi, Toplu İcra, Çalgı Toplulukları, Birlikte Çalma

\section{Giriş}

Müzik eğitiminin önemli unsurlarından biri olan çalg1 eğitimi; müzik kültürünün öğrenilmesi, öğretilmesi ve yaşatılması açısından göz ardı edilemeyecek bir öneme sahiptir. Çalg1 eğitiminin temel hattını oluşturan bireysel ve toplu icra eğitimleri ise bireye kazandırılması gereken beceriler olarak görülmektedir (Özmenteş, 2005). En az bireysel icra eğitimi kadar önemli olan toplu icra eğitiminin; birlikte çalma, müzikal paylaşım, toplu müzik üretme bilinci gibi yetkinlikleri bireye kazandırdığı ve çalg1 eğitimine önemli derecede katkı sağladığı gözlemlenebilmektedir. Toplu icra eğitimi içerisindeki bir diğer önemli konu ise, akranların etkileşimleridir (Nielsen vd., 2018). Bu etkileşime ve bireyler üzerindeki etkisine Türk halk müziği (T.H.M.) toplu icrası içerisinde de rastlamak mümkündür.

Türk halk müziği toplu icra eğitimini etkileyen farklı dinamikler vardır. Bu faktörlerden bir tanesi geçmişten günümüze ulaşan yerel toplu icra gelenekleridir. Anadolu, toplumsal hayatta pek çok kültürel zenginliği içerisinde barındıran ve bunlara bağlı olarak pek çok ritüel ve geleneğe ev sahipliği yapmış bir coğrafyadır. İnsanların toplumsal hayatının önemli bir parçasını da halk müziği teşkil etmektedir. Türk halk müziği, toplumun ortak geçmişini, zevkleri ve eğlence anlayışını, dolayısıyla ortak bir kültür, gelenek ve göreneği temsil ederek kültürel mirasın aktarıcısı görevindedir. Bir müzik yapma biçimi olarak toplu icra, usta çırak geleneğiyle beraber günümüze aktarılan önemli bir eğitim yöntemidir. Toplu icranın beraberinde getirdiği birlik içindeki uyum anlayışı kültürel olarak sosyalleşmenin ve müzikal gelişimin önemli bir ayağını oluşturmaktadır. Türk halk müziği toplu icra geleneklerinin birçok örneğine, Anadolu'nun farklı bölgelerinde rastlanabilmektedir. Kürsübaşı faslı, yâren meclisi sohbetleri, sıra geceleri, barana toplantıları ve oturak âlemleri gibi etkinlikler bu geleneklere örnek gösterilebilir (Öcal, 2013). Ülkemizde, geleneksel toplu icra ile ilgili araştırmalar yapılmasına karşın bu çalışmalar konunun müzikal yönü ile ilgili kısıtlı bilgiler veren; daha çok toplu icra geleneklerinin kökenleri, icra edildiği yerel etkinliklerin kimler tarafindan nerede yapıldı ğı, etkinlik esnasında izlenen sıralama, yol, yöntem; etkinliklerde gerçekleştirilen adetler, etkinlik sırasında kullanılan çalgılar gibi konulara eğilen çalışmalardır. Toplu icra geleneklerinin icra özelliklerini ve üslubunu müzikal anlamda açıklayıcı net bilgiler ve notalar sunan çok sayıda çalışmaya ihtiyaç vardır.

Günümüz Türk halk müziği toplu icra eğitimini etkilediği düşünülen diğer bir faktör de kurumsal yapıların çatısı altında yapılan toplu icralardır (Ekim, 2019). Cumhuriyetin ilanı sonrası ulus-devlet modelini benimseyen Türkiye Cumhuriyeti Devletinin kurucu kadroları, Ziya Gökalp'in halk müziklerini "Garp fenniyle" (Batı müziği teknikleri ile) işleyerek ulusal ve çağdaş bir müziğe ulaşılabileceği fikrini "ulusal müzik ideali" olarak benimsemiştir (Öztürk, 2016). Bu bilincin yaygınlaşması ve aktarılması amacıyla "ulusal müzik ideali" çerçevesinde "milli ve tabii" olarak görülen halk müziği ezgilerinin derlenmesi başta olmak üzere pek çok proje hayata geçirilmiştir (Öztürk, 2018: 52). Köy enstitüleri, halkevleri gibi devlete bağlı kurumlarda yapılan müzik eğitimi (Alpagut, 2013), halkevlerinde yapılan toplu icra çalışmaları (Coşkun, 2006: 28) ve halk müziği ezgilerinin derleme çalışmaları (Tunalı, 2013: 72) gibi çalışmalar bu ideal doğrultusunda yapılmış öncü çalışmalardır. Diğer yandan, radyo yayıncılığı ile derlenen halk türkülerinin çeşitli topluluklar ile icra edilmesi süreci de başlamıştır (Parlak, 2016: 212). Dönemin teknolojik kitle iletişim araçlarının başında gelen radyo ve özellikle 1940'lı yılların başlarında radyo bünyesinde kurulan 
"Yurttan Sesler" topluluğu tarafından yapılan yayınlar halk müziğinin farklı formlarının tüm yurda ulaşması ve sevilmesi hususunda etkili olmuştur (Parlak, 2016: 212). Bu tür çalışmalar ile halk müziğinin kurumsallaşması sağlanmış ve kurumsal yapı içerisinde yapılan toplu icralara tüzel kişiler tarafından belirli normlar getirilmek istenmiştir (Ersoy, 2014: 938).

Anadolu'nun muhtelif bölgelerinde, kültürel ve coğrafi yapıların etkisiyle yörelere has çalgı(lar) ve özgün müzik tınıları mevcuttur. "Yurttan Sesler Topluluğu" kurumsal yapısının altında yapılan toplu icralarda bu çalgıların biçimsel yapılarına (Açın 1998, Akt. Erdemir, 2013 :33), çalınış tekniklerine (Parlak, 1998:70-71), kullanılan perde sistemine (Parlak, 2016: 217-218) ve akort sistemlerine (Alpyıldız, 2012) kadar pek çok alanda standardizasyon çalışmaları yapılmıştır. Bu süreç sonunda çalgı olarak saz/bağlama grubunun "bütün yerel çalgıların işlevini üstlenerek deyim yerindeyse tek söz sahibi olduğu" (Ekim, 2019: 2239), "bozuk düzen" akort sisteminde (Alpyıldız, 2012) mizraplı saz/bağlama icra tekniklerinin (Parlak, 1998:70-71) saz/bağlama icra stili olarak tercih edildiği, yöresel üslupların saz/bağlama icrasında "sağ el mızrap kalıpları" aracılığıyla ifade edildiği (Parlak, 2016: 221-222: Ekim, 2019: 2239) kurum içerisinde benimsenen bir toplu icra üslubu ortaya çıkmıştır. Bu icra üslubunun dokusal özelliği, saz/bağlama grubu tarafından üretilen yoğunlukla homoritmik mızrap kalıpları ile şekillenmiş ezgilerin üzerine az sayıda "renk saz"ın ve koronun monofonik ya da heterofonik icrası olarak tarif edilebilir. Benimsenen bu icra şekli, zamanla yöresel üslubun dışında/üzerinde "radyo üslubu" ya da "TRT tavrı" (Çevik, 2016: 59) diye isimlendirilen bir üslubun oluşmasına sebep olmuş ve bu üslup çalgı topluluğunun birlikteliğini sağlayan bir etmen olarak etkin kılınmıştır (Ekim, 2019: 2239). Bu doğrultuda, kendi müzik kültürü ve geleneği içerisinde bir arada icra edilmeyen çalgıların yöresel dinamikleri dışında yeni bir "oturtum" ve "sound" anlayışıyla bir araya getirilmesi Yurttan Sesler Topluluğu ile meydana gelen bir durumdur (Ersoy, 2014: 939-940).

Yurttan Sesler Topluluğu, bir icra topluluğu olmasının yanı sıra döneminin mevcut şartları içerisinde etkin bir halk müziği eğitim ve aktarım kurumu haline gelmiştir (Alpyıldız, 2012: 88). Bu topluluk içerisinde yetişmiş çalgı ve ses sanatçıları radyonun kurumsal yapısının dışında, bireysel ve toplu icra eğitimine yön vermiş kişiler olarak karşımıza çıkmaktadır (Ekim,2019). Türk Müziği alanındaki ilk konservatuar olan 1976 yılında İstanbul'da eğitim hayatına başlayan "İstanbul Türk Musikisi Devlet Konservatuarı"nın kurucu kadrosunu da radyo eksenli icracılar oluşturmaktadır (Parlak, 2016: 231). Daha sonra İstanbul Teknik Üniversitesi'ne bağlanarak "İ.T.Ü. Türk Musikisi Devlet Konservatuarı" adını alan bu kuruluş Türkiye'nin farklı bölgelerinde açılan Türk Musikisi Devlet Konservatuarlarına model olmuştur. Böylece, radyo bünyesinde kabul görmüş olan toplu icra üslubu akademik eğitimde ve hatta devlet kurumları bünyesinde ve dışında belediye, dernek, vakıf, özel teşebbüsler tarafından kurulan diğer halk müziği topluluklarında da benimsenerek yaygınlaşmıştır (Altınay, 2011: 57). Son yıllarda bu toplu icra modelinde de çeşitli fikirler doğrultusunda farklı T.H.M Orkestrası toplu icra model anlayışları ortaya çıkmıştır (Altınay, 2011: 57-58). Bunların başında, orkestra içerisinde halk müziği çalgılarının yanı sıra farklı müzik türlerinde icra edilen çalgıların bu toplu icra modeline eklemlenmesi ile ortaya çıkan T.H.M. orkestrası modeli gelmektedir (Coşkun,2006:24).

Üst düzey icracıların özel girişimleriyle oluşan topluluklar tarafından çeşitli müzik anlayışları ile yapılan icralar da toplu icra ve eğitimini etkileyen başka bir unsur olarak sayılabilir. Halk müziği içerisindeki gelenek kavramının toplumsal dönüşümlere paralel olarak sürekli bir değişim içerisinde olması (Markoff, 1990/1991), cumhuriyetin kuruluşundan itibaren bir tartışma konusu olan ve günümüzde dahi devam eden Türk halk müziğinin çok seslendirilmesi konusu (Türkmen, 2007), Türk halk müziği dışında yer alan müzik akımlarının halk müziği icrası üzerindeki etkileri (Türkmen, 2010) ve bu etkilerin toplu icraya yansıması gibi faktörler halk müziği icracılarının çeşitli müzik anlayışlarıyla farklı arayışlar içerisinde bulunmalarına sebep olmuştur. Buna bağlı olarak radyo üslubu çerçevesinde yapılan toplu icra biçiminin dışında yeni ve özgün toplu icra çalışmaları yapılmıştır (Duygulu, 2002). 
1983 'ten itibaren Arif Sağ, Musa Eroğlu, Muhlis Akarsu, Yavuz Top tarafından yapılan ve farklı sanatçıların da dahil olması ile sürdürülen "Muhabbet" albüm serisi bir başka toplu icra modelini önermesi bakımından dikkat çekicidir. Bu albüm serisinde "bozuk düzen" yerine "bağlama düzeni", "uzun saplı bağlama" yerine "kısa saplı bağlama" kullanılmış (Çalışkan, 2018); ritmik mızrap kalıplarına dayalı "radyo üslubu" çerçevesindeki "yöresel tavır" anlayışından uzak, ezginin ön plana çıkarıldığı, "bağlama düzeni"nden kaynaklı olarak paralel dörtlü, beşli yürüyüşlerin sıklıkla duyulduğu (Ekim, 2019 : 2239), tınısal ihtiyaçlar doğrultusunda "bas bağlama" gibi yeni çalgıların toplu icraya "heterofonik" doku içerisinde uyarlandığı bir anlayış ortaya çıkmıştır.

Bu süreçten önce 70'li y1llarda yükselen "Anadolu Pop”, “Anadolu Rock”, "Protest Müzik” gibi müzik akımlarında türkülerin "modernize" edilerek çok sesli olarak yorumlandığı bir dönem vardır (Camgöz,2019:113). Öte yandan, türkülerin Türk Halk Müziği icracıları tarafından "deneme", "arayış", "yenilik" gibi ihtiyaçlar çerçevesinde homofonik, polifonik dokular içerisinde "çok sesli" olarak seslendirilmesi yine 80'li yıllarda ortaya çıkan bir gelişmedir. Arif Sağ’’n 1983 yılında yaptığı "İnsan Olmaya Geldim" albümündeki aynı ismi taşıyan eserde saz/bağlama, kaval, kemane, bas bağlama ve koro çok partili bir anlayış içerisinde kullanılmıştır. Yavuz Top önderliğinde kurulan "Yavuz Top Halk Çalgıları Orkestrası" da bu dönemde halk müziğinde çok partili, çok sesli toplu icra modeli olarak ortaya konulmuş önemli bir çalışmadır. "Iklı̆̆" gibi yeniden üretilmiş çalgıların da bir dönem kullanıldığ 1 bu topluluk, çok sesli olarak düzenlenmiş bazı eserleri kaydedebilmiş ancak canlı konser verme firsatını bulamamıştır (Coşkun, 2006: 63). Bu eserlerden özellikle "Ötme Bülbül Ötme" saz ailesi ile birlikte birçok halk çalgısının ve çok sesli koronun kullanıldığı bir düzenleme örneği olarak benimsenmiş ve literatüre girmiştir. Bugün de bu esere yapılan düzenleme farklı varyasyonlar Türk halk müziği orkestralarında icra edilmektedir. Arif Sağ ve Musa Eroğlu tarafından yapılan "Bağlama Resitali" albüm serisinde ise "bağlama duo" / "bağlama ikilisi" modeli ortaya konulmuş, burada monofonik-heterofonik icranın yanısıra, doğaçlamaya dayalı "ostinato", dem ve paralel ezgi hareketlerine dayanan çok sesli unsurlar da duyulmaktadır.

Yine bu dönemde, Ertuğrul Bayraktar, Erdal Tuğcular gibi akademisyenler, halk müziği çalgılarının çok seslendirilmesi ve toplu icra hususunda çalışmalar yapmışıır' ${ }^{1}$ Kemal İlerici'nin ortaya koyduğu "dörtlü armoni" anlayışı ile Ertuğrul Bayraktar tarafından düzenlenmiş eser örneklerinden bazıları Okan Murat Öztürk öncülüğünde kurulan "Bengi Bağlama Üçlüsü̈", tarafindan icra edilmiştir. Bir bağlama topluluğu olarak "Bengi”, "yeni gelenek" mottosu ile farklı "deneysel" çalışmalar da yapmış, "Divan Sazı-Tanbura-Cura" üçlüsünü temel alarak, saz ailesinin hemen her boyut ve türdeki üyesini icralarında kullanmış, albümler dışında bu icra biçimini konserlere de taşımıştır. Bu bakımdan Bengi Bağlama Üçlüsü önemli bir toplu saz icrası modeli ortaya koymuştur ${ }^{3}$. Erdal Tuğcular tarafindan özellikle saz/bağlama grubu için üretilen eserler de literatürde yerini almış ve icra edilmiştir.

Uzun zamandır Anadolu'da ve çevre coğrafyalarda var olan "mızrapsız saz çalım teknikleri” de yine 1980'lerde şehir müzik kültürü içerisine girmiş bir olgudur (Çalışkan, 2018: 24). Özellikle 90'lardan itibaren Erol Parlak ve Erdal Erzincan gibi usta icracıların elinde ezgisel, ritmik ve armonik olarak yeni anlatım olanakları sunan bu teknik pek çok albümde etkin olarak kullanılmıştır (Ayyıldız, 2018). Bu dönem, halk müziği albümlerinde tınısal değişimlerin yaşandığı, çok partili, çok sesli

\footnotetext{
${ }^{1}$ Kültür ve Turizm Bakanlığı Güzel Sanatlar Genel Müdürlüğü’nce Ertuğrul Bayraktar, Erdal Tuğcular, Muammer Sun, Mehmet Özbek ve Burhan Önder'den oluşturulan komisyon tarafından yazılan "Türk Halk Müziği Çalgı Bilgisi" (Özbek vd., 1989) ve Erdal Tuğcular tarafından yazılan "Bağlama ve Halk Müziği Toplulukları İçin Çoksesli Türküler Dağarcığı" (Bayraktar,1989) kitabı bu alanda yapılmış bir çalışma olarak örnek gösterilebilir.

2 "Bengi Bağlama Dörtlüsü" adıyla kurulan topluluk üye sayısının değişimine paralel olarak bugün "Bengi Bağlama Üçlüsü” olarak sanat yaşamına devam etmektedir. Topluluğun bugünkü üyeleri Okan Murat Öztürk, Özay Önal ve Erdem Şimşek'tir.

3 "Lâl Bağlama Topluluğu", "Tanbura Trio" gibi bağlama grupları bu modeli benimseyip çeşitlendirerek, "yeni arayışlar" doğrultusunda ağırlıkla çok partili deneysel çalışmalar yapmışlardır.
} 
düzenlemelerin yoğunlukla icra edildiği ve halk müziği icralarındaki çok sesli uygulamaların "normalleştiği" bir dönem olmuştur. Bu uygulamalardaki anlayış doğrultusunda, Erol Parlak, "Türkiye'de El ile Bağlama Çalma Geleneği” isimli doktora tezinde mızrapsız ve mızraplı saz/bağlama çalım tekniklerini birleştiren, bir toplu icra modeli önermiş (Parlak, 1998: 212-213); sonraki dönemde "Erol Parlak Bağlama Beşlisi" adı altında öğrencileri ile birlikte bu modeli uygulayarak hayata geçirmiştir ${ }^{4}$. Bu model yapısında yer alan sazlar incelendiğinde topluluğun, 1 adet mızraplı tekniklerle icra edilen sazın yanında, el ile çalınan 2 adet çelik telli (soprano) saz, 1 adet sırma telli (tenor) saz ve 1 adet "bassaz"dan oluştuğu görülmektedir ${ }^{5}$. "Farklı boyutlarda sazların getirdiği tınısal zenginliğin bir orkestra mantı̆̆ıyla bir araya gelebileceği düşüncesi”nden (Coşkun, 2006: 55) yola çıkan Erdal Erzincan, "Erdal Erzincan Bağlama Orkestrası"nı kurarak, bu toplulukta dikey ve yatay çok seslilik unsurlarının kullanıldığı düzenlemelere yer vermiştir.

"Geleneksel toplu icra üslubu" ve "radyo üslubu" çerçevesinde ortaya çıkan toplu icra üsluplarının yanı sıra "yenilikçi" yaklaşımlar doğrultusunda yapılan çalışmalarda ortaya konulan toplu icra üslupları da akademi içerisinde geçmişten günümüze dek farklı fikirler aracıllğıyla şekillenen Türk halk müziği toplu icra çalışmalarını ve eğitim anlayışını etkilemiştir ${ }^{6}$.

\section{Araştırmanın Amacı ve Önemi}

Üniversitelerimiz bünyesinde yer alan konservatuvarlar, müzik ve sahne sanatları fakülteleri ve icra sanatları fakültelerinde lisans düzeyinde çeşitli ders adları altında verilmekte olan "Türk halk müziği toplu icra eğitimi" içerikli derslerin yöntem ve muhtevasının tespit edilmesi, karşılaşılan problemlerin belirlenmesi; elde edilen bulgular doğrultusunda sonraki süreçte "Türk halk müziği toplu icra eğitimi" bağlamında ortaya çıkan problemlerin çözümüne ve ne türde araştırmalar yapılması gerektiğine yönelik önermeler yapılabilmesi bu araştırmanın amacını oluşturmaktadır.

$\mathrm{Bu}$ çalışmanın toplu icra, toplu çalma ve söyleme geleneğiyle ilgili yapılacak araştırmalara kaynak oluşturması ve referans olması bakımından önem arz ettiği düşünülmektedir.

\section{Araştırmanın Problemi}

Bu araştırmanın problem cümlesini, "Yükseköğretim kurumlarında Türk halk müziğinde toplu icra eğitimi ne şekilde uygulanmaktadır ve uygulama içerisinde karşılaşılan problemler nelerdir?" oluşturmaktadır.

\section{Araştırmanın Yöntemi}

$\mathrm{Bu}$ araştırmada anket yöntemi içerisinde araştırma için gerekli veriler Google Forms aracılığıyla çevrimiçi (online) olarak yapılandırılmış görüşme formu ve sıklık belirten likertli ölçek (Hiç, Nadiren, Orta Sıklıkta, Genellikle, Çok Sık) yolu ile elde edilmiştir. Görüşme formu yoluyla tespit edilen bulgular nitel ve nicel veri analizi yöntemlerinden faydalanarak yorumlanmıştır. Sıklık belirten likertli ölçek yoluyla elde edilen veriler ise hem frekans(n) ve yüzde (\%) olarak gösterilmiş, hem de verilerin ağırlıklı ortalamasından elde edilen bulgulara dayanarak yorumlanmıştır. Elde edilen verilere dayanarak üretilen yüzdelik sayısal, değerler virgülden sonra tek hane olacak şekilde yuvarlanmıştır. Soruların şıklarına verilen cevapların yüzdelik değerleri "hiç" şıkkı için 0, "nadiren" ş1kk1 için 0.25 , "orta sıklıkta" şıkk1 için 0.5 , genellikle şıkk1 için 0.75 ve "çok sık" şıkk1 için 1

\footnotetext{
${ }^{4}$ Daha sonra farklı sanatçılar tarafından kurulan Dörttelli Bağlama Grubu, Bandura Bağlama Topluluğu, İstanbul Bağlama Dörtlüsü gibi çok sesli, “deneysel” çalışmalar yapan topluluklar, bu toplu icra modelini benimsemişlerdir.

${ }^{5}$ Bassaz dışında topluluk bünyesinde kullanılan sazlar "orta boylu" sazlar olup; ihtiyaç duyulan geniş ses alanı farklı boyuttaki saz kullanımları yerine farklı kalınlıkta teller kullanılarak elde edilmiştir. Bassaz dışındaki tüm sazlar "bağlama düzeni" ile akort edilmiș "kısa saplı" sazlardır. Bassaz elektro-akustik bir saz olup çello telleri kullanılmıștır.

${ }^{6} \mathrm{Bu}$ toplu icra çalışmalarına, Mehmet Ali Özdemir yönetiminde konserler veren "Halk Çalgıları Orkestrası", İ.T.Ü. Türk Müziği Devlet Konservatuvarı bünyesinde Erol Parlak yönetmenliğinde yapılan "Bir Nefes Anadolu”, Şahin Saruhan yönetmenliğinde yapılan "Şahin Saruhan Araştırma Topluluğu Performans Grubu" gibi akademik ortamda yapılan ve çok sesli düzenlemeler icra eden topluluk çalışmaları örnek gösterilebilir.
} 
çarpanlarıyla çarpılmış ve elde edilen verilerin toplanması ile "ağırlıklı ortalama değerleri" bulunmuştur.

$\mathrm{Bu}$ çalışmanın araştırma yöntemi ile elde edilen veriler araştırma ve yayın etiği ilkelerine uygun olarak hazırlanmıştır.

\section{Araştırmanın Modeli}

$\mathrm{Bu}$ araştırma nitel ve nicel araştırma tekniklerinin kullanıldı ğ betimsel bir çalışma olup, tarama modelini esas almaktadir.

\section{Araştırmanın Sayıltıları (Varsayımları)}

$\mathrm{Bu}$ araştırmada; toplu icra derslerini yürütmüş ve hali hazırda yürütmekte olan öğretim elemanlarının alanlarında uzman olduğu ve araştırmaya katılan kişilerin kendilerine yöneltilen sorulara içtenlikle cevap verdikleri varsayımlarıyla hareket edilmiştir.

\section{Araştırmanın Sınırlılıkları}

Konservatuvarlar, müzik ve sahne sanatları fakültelerinin lisans programlarında, son beş yıl içerisinde "Türk halk müziği toplu icra" içeriği taşıyan dersleri yürütmüş veya hali hazırda bu dersleri yürüten ve bu araştırmaya gönüllü olarak katılan öğretim elemanlarından elde edilen veriler; araştırmanın sınırlılığını oluşturmaktadır.

\section{Evren ve Örneklem}

Bu araştırmanın evrenini Türkiye'de yükseköğretim kurumlarında "Türk halk müziği toplu icra" içerikli dersleri yürütmüş veya hali hazırda yürüten eğitimciler, örneklemini ise son beş yıl içerisinde konservatuvarlar, müzik ve sahne sanatları fakültelerinde "Türk halk müziği toplu icra" içeriği taşıyan dersleri yürütmüş veya hali hazırda yürütmekte olan, gönüllü olarak bu araştırmaya katılmak isteyen ve ulaşılabilen öğretim elemanları oluşturmaktadır.

\section{Verilerin Toplanması ve Çözümlenmesi}

Araştırmada öncelikle literatür taraması yapılıp araştırmaya kaynak olacak çalışmalar belirlenerek incelenmiştir. Önceden belirlenen alan uzmanları ile Google Forms internet anket sistemi yoluyla iletişim sağlanıp konuya yönelik sorulara cevaplar alınmıştır. Görüşme verileri daha sonra nitel ve nicel araştırma yöntemleriyle analiz edilerek sonuçlara ulaş1lmaya çalış1lmıştır.

\section{Katılımcı Profili}

$\mathrm{Bu}$ araştırmaya katılan katılımcıların profili şu şekildedir:

Katılımcıların cinsiyeti: \%91,7 Erkek $(n=22)$, \%8,3 Kadın $(n=2)$; katılımcıların eğitim durumu: \%41,7 Yüksek Lisans mezunu $(\mathrm{n}=10), \% 41,7$ Doktora mezunu $(\mathrm{n}=10), \% 8,3$ Sanatta Yeterlilik mezunu ( $\mathrm{n}=2), \% 8,3$ Lisans mezunu $(\mathrm{n}=2)$.

Katılımcıların lisans düzeyinde mezun oldukları bölümler: \%62,5 Türk Müziği Devlet Konservatuvarı ( $\mathrm{n}=15), \% 12,5$ Müzik Eğitimi Bölümü ( $\mathrm{n}=3)$, \%4,2 Güzel Sanatlar Fakültesi $(\mathrm{n}=1)$ ve \%20,8 müzik dışı bölümler ( $\mathrm{n}=5)$ şeklinde tespit edilmiştir. Katılımcılardan 16'sı $(\% 66,7)$ lisans ya da lisansüstü eğitim sürecinde Türk halk müziği toplu icrası ile ilgili en az bir ders aldıklarını 8 kişi $(\% 33,3)$ ise konuya dair herhangi bir ders almadıklarını belirtmiştir.

Araştırmaya katılan öğretim elemanlarının sanatsal deneyim durumu incelendiğinde; katılımcıların tamamı, daha önce Türk halk müziği toplu icra üzerine sanatsal çalışmalar (faaliyetler) içerisinde yer aldığını belirtmiştir. Bu sanatsal faaliyetlerin çoğunluğunu konserler, televizyon-radyo programları ve albüm projelerinin oluşturduğu görülmektedir. 
Bu araştırmaya $24(\mathrm{n}=24)$ öğretim elemanı katılmış olup, katılımcı profilinin dağılımı Tablo 1 'de görüldüğü gibidir.

Tablo 1: Katılımcıların Ders Verdiği Eğitim Kurumu ve Kurumlara Göre Katılımcı Sayısı

\begin{tabular}{ll} 
Katılımcıların Ders Verdiği Eğitim Kurumu & $\begin{array}{l}\text { Kurumlara Göre } \\
\text { Katılımcı Sayısı }\end{array}$ \\
\hline
\end{tabular}

\begin{tabular}{ll}
\hline İ.T.Ü Türk Müziği Devlet Konservatuvarı & 4 \\
\hline Gaziantep Üniversitesi Türk Müziği Devlet Konservatuvarı & 3 \\
\hline Hacettepe Üniversitesi Ankara Devlet Konservatuvarı & 2 \\
\hline Antalya Devlet Konservatuvarı & 2 \\
\hline Kafkas Üniversitesi Devlet Konservatuvarı & 2 \\
\hline Ankara Müzik ve Güzel Sanatlar Üniversitesi İcra Sanatları Fakültesi & 1 \\
\hline Ankara Hacı Bayram Veli Türk Müziği Devlet Konservatuvarı & 1 \\
\hline Sakarya Üniversitesi Devlet Konservatuvarı & 1 \\
\hline Fırat Üniversitesi Devlet Konservatuvarı & 1 \\
\hline Ordu Üniversitesi Müzik ve Sahne Sanatları Fakültesi & 1 \\
\hline Afyon Kocatepe Üniversitesi Devlet Konservatuvarı & 1 \\
\hline Namık Kemal Üniversitesi Türk Müziği Devlet Konservatuvarı & 1 \\
\hline Haliç Üniversitesi Devlet Konservatuvarı & 1 \\
\hline Ege Üniversitesi Türk Müziği Devlet Konservatuvarı & 1 \\
\hline Kocaeli Üniversitesi Devlet Konservatuvarı & 1 \\
\hline Anadolu Üniversitesi Devlet Konservatuvarı & 1 \\
\hline
\end{tabular}

Katılımcılara daha önce bir T.H.M. topluluğunda ne tip görevler aldıkları sorusu sorulduğunda aşağıdaki grafikte görünen yanıtları vermişlerdir.

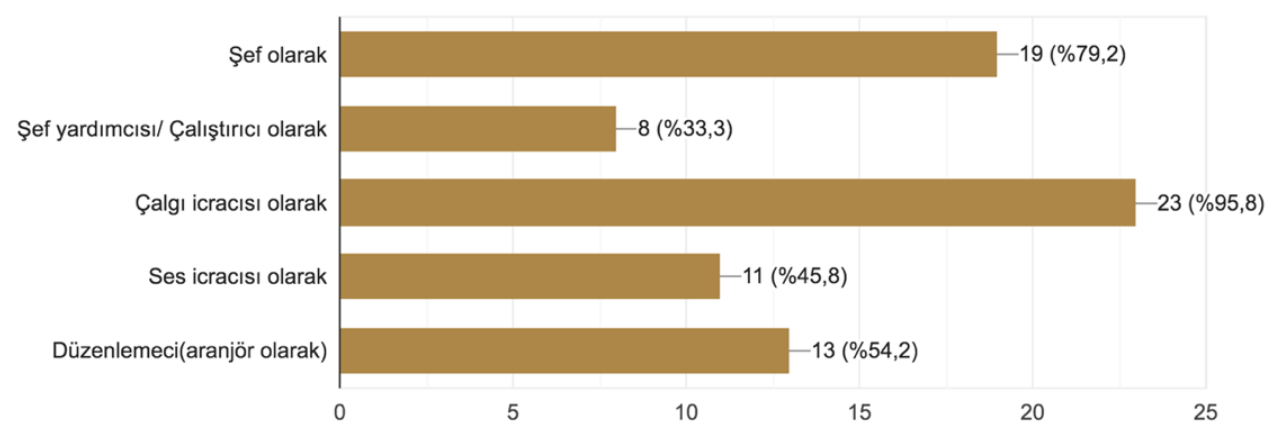

Şekil 1: Katılımcıların T.H.M. Toplu icra deneyimleri ${ }^{7}$

Katılımcıların yalnızca \%8,3'ü ( $\mathrm{n}=2$ ) toplu icra ile ilgili bilimsel araştırmalarda bulunduğunu belirtmiştir. Katılımcıların icra edebildikleri çalgılar incelendiğinde, 19 kişinin saz/bağlama ailesi, 3 kişinin "kaval" 2 kişinin "zurna" 2 kişinin "sipsi”, 1 kişinin "keman", 1 kişinin "bas gitar", 1 kişinin "tar", 1 kişinin "ud", 1 kişinin "cümbüş" icra ettiğini belirttiği tespit edilmiştir.

\footnotetext{
${ }^{7}$ Katılımcıların birden fazla seçeneği seçebildikleri bu soruya verilen cevapların gösterildiği grafikte, sütunların karşısında gösterilen sayılar, 24 kişi içerisinde kaç kişinin ilgili şıkkı seçtiğini belirtmekte olup; yüzdeler ile belirtilen sayılar ise toplam kişi sayısına göre bu şıkkı belirten kişilerin oranını göstemektedir.
} 


\section{Anket Sorularının Tasarımı}

Anket sorularının tasarlanma sürecinde, ilk olarak araştırmanın problem cümlesi olan "Türk halk müziğinde toplu icra eğitimi ne şekilde uygulanmaktadır ve uygulama içerisinde karşılaşılan problemler nelerdir?" sorusuna yönelik cevaplar aranmaya çalışılmıştır.

$\mathrm{Bu}$ araştırmanın giriş bölümünde bahsi geçen, yükseköğretim kurumlarında Türk halk müziği toplu icra eğitimini etkilediği öngörülen unsurlardan "yöresel icra üslubu", "radyo üslubu" ve modernist yaklaşımlarla oluşturulan "yenilikçi”" üslupların Türk halk müziği toplu icra derslerinin içeriğinde ne derecede öne çıktığını tespit etmeye yönelik sorular tasarlanmıştır. $\mathrm{Bu}$ sorular tasarlanırken, bahsi geçen unsurların "toplu icraya yönelik topluluk modelleri", "müzikal doku özellikleri" ve "çalgı türü tercihleri”"nden yola çıkılmıştır. Geçmişten günümüze çeşitli anlayışlarla kurulan topluluklarda saz/bağlama çalgısının ağıllıkta olmasını ve üslup oluşumunda bu çalgının üzerinde yapılan tercihlerin etkisini gözeterek, eğitimde bu çalgının kullanımı ile ilgili "topluluk içindeki saz/bağlama icracısı sayısı" ve "akort sistemi tercihleri"ni tespit etmeye yönelik sorular üretilmiştir. Farklı üslupların etkisiyle yapıldığg düşünülen toplu icra eğitiminde ihtiyaç duyulacak olas1 eğitim materyallerinin ne ölçüde kullanıldığına, yeterliliğine, eğitim materyallerinin kim(ler) tarafından belirlendiğine ve eğitim materyallerinden kaynaklanan problemlerle ne ölçüde karşılaşıldığına yönelik sorular tasarlanmıştır. Ayrıca, farklı tipte toplu icra modellerinin uygulanma sürecinde karşılaşılan problemlerin neler olduğuna, görülme sıklığına yönelik sorular üretilmiş; ders işleyişi, dersin değerlendirilme şekli, dersin müfredat içerisindeki yerinin ne ağırlıkta olduğu ve ne ağırlıkta olması gerektiğine yönelik düşüncelerin tespit edilmesi amaciyla farklı soruların tasarlanmasına da ihtiyaç duyulmuştur. Seçenek sunan sorularda daima açık uçlu "diğer (varsa belirtiniz)" şıkkı eklenmiştir.

\section{Bulgular ve Yorumlar}

\section{Toplu İcranın Önemine Dair Görüşler}

Öğretim elemanlarının kişisel görüşlerine yer verilen bu bölüm içerisinde katılımcılara “Türk halk müziği toplu icra derslerinin bireysel çalgı eğitimine ne düzeyde katkı sağladığını düşünmektesiniz?” sorusu yöneltilmiştir.
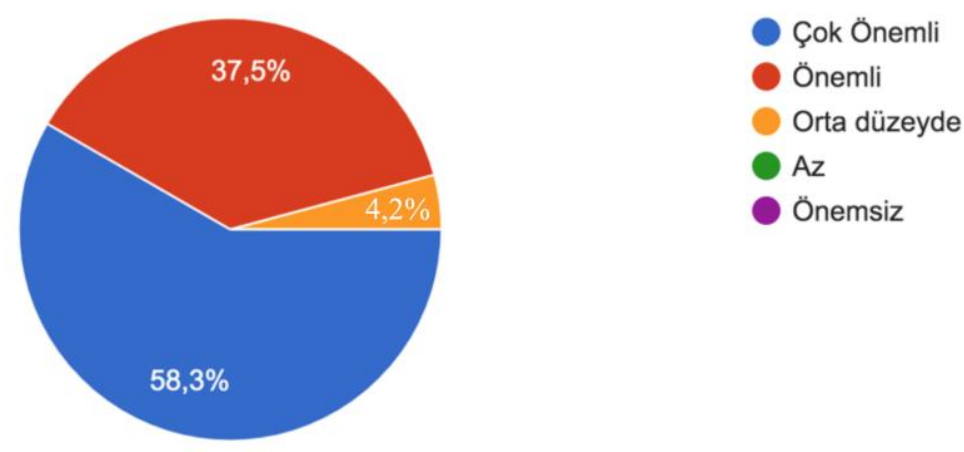

Şekil 2: "Türk halk müziği toplu icra derslerinin bireysel çalg1 eğitimine ne düzeyde katk1 sağladığını düşünmektesiniz?" sorusuna verilen cevapların grafik üzerinde gösterimi

Şekil 2'de görüldügü üzere öğretim elemanlarının $\% 58,3$ 'ü $(n=14)$ toplu icra derslerinin bireysel çalg1 eğitimine çok önemli, \%37,5'i $(n=9)$ önemli \%4,2'si $(n=1)$ orta düzeyde katk1 sağladığını belirttikleri görülmektedir. Eğitmenlerin büyük bir çoğunluğunun, T.H.M. toplu icra derslerinin bireysel müzik eğitimine katkısının önemli olduğunu düşündükleri tespit edilmiştir.

Türk halk müziği toplu icra derslerinin bireysel icra eğitimine katkısının boyutlarını tespit etmek amacıyla "Düşündüğünüz katkıları kısaca açıklayınız? sorusu katılımcılara açık uçlu olarak yöneltilmiştir. Katılımcılardan elde edilen veriler arasında "kişinin kendi teknik seviyesini 
tartması", "çalışma disiplini sağlanması", "konsantrasyonun arttırılması", "partisyon takibi yetisinin daha üst bir seviyeye taşınması", "perde baskıları ve entonasyon problemlerinin çözümü için gerekli olan dinleyerek çalma yetisinin geliştirilmesi", "dengeli icra niteliklerinin kazanılması", "bireysel icrada müzikal dinamiklerin, ritim dengesinin oturması", "farklı çalgıları tanımanın sağlanması", "düzenleme çalma tecrübesi kazanılması", "eşlik partisyonu çalma kabiliyetinin gelişmesi”, "birlikte konser hazırlama deneyimi edinilmesi", "deşifre seviyesinin arttırılması", "ortak bir icra ruhu yakalanması", "motivasyonun arttırılması", "öğrencide müzik yapma hissi ve tatminin oluşması", "yaratıcı rekabet ortamının arttırılması", "kontrollü ve korunaklı sahne tecrübesi edinilmesi", "farklı fikir ve müzikal düşünceleri icra ederek görme firsatının oluşturması ", "yaratıcılık kavramıyla tanışılması", "grup çalışması ile bireysel çalışmaya göre daha büyük ve etkili sonuçları deneyimleme ortamının sağlanması", "ekip çalışmasında sorumluluk bilincini geliştirmesi”, "icracı yalnızlığının yok edilmesi", "egoların törpülenmesi", "transpoze, modülasyon ve farklı çalgılara ait pozisyon kavramlarıyla alakalı çalgı uyarlamaları içerisinde bireysel icraya dair yeni kazanımlar elde edilmesi", "topluluk içerisinde icra yaparak öğrencinin kendine güven duygusunun sağlanabilmesi" vb. katkılar toplu icra derslerinin bireysel icraya olan katkıları olarak belirtilmiştir.

\section{Toplu İcra Eğitimini Etkileyen Anlayışlar}

Araştırmanın giriș bölümünde T.H.M. toplu icra eğitimini etkilediği düşünülen faktörlerin eğitime etki düzeyini tespit etmek amacıyla katılımcılara bazı sorular yöneltilmiştir.

Katılımcılara yöneltilen "Türk halk müziği toplu icra derslerinde nasıl bir eğitim modeli yöntemi uyguluyorsunuz?" sorusu ile katılımcıların ders işleyiş̧inde uyguladığı eğitim modelinin ne tür (tek partili/monofonik ve/veya çok partili/homofonik-heterofonik-polifonik) çalışmalara dayandığ 1 tespit edilmeye çalışılmıştır. Bu soru çoktan seçmeli ve açık uçlu olarak sorulmuş olup verilen cevaplar aşağıdaki grafikte görülmektedir.

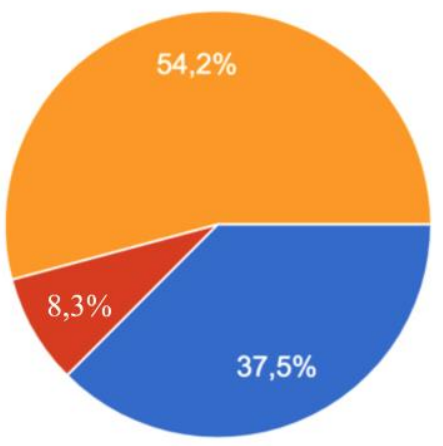

Tek partili toplu icra çalışmaları ile yapılan bir eğitim modeli (Tek Sesli)

Çok partili toplu icra çalışmaları ile yapılan bir eğitim modeli (Çok Sesli)

Her ikisinin de belirli bir sistem içerisinde uygulandığı bir eğitim modeli

Şekil 3: "Türk halk müziği toplu icra derslerinde nasıl bir eğitim modeli yöntemi uyguluyorsunuz?" sorusuna verilen cevapların grafik üzerinde gösterimi

Şekil 3'teki grafikte görüldüğü üzere katılımcıların \%54,2'si $(n=13)$ hem tek partili hem çok partili toplu icra çalışmalarını içeren bir eğitim modelini benimsediğini belirtmekte olup \%37,5'i $(\mathrm{n}=9)$ yalnızca tek partili çalışmalara dayanan, \%8,3' $\ddot{\mathrm{u}}(\mathrm{n}=2)$ ise çok partili toplu icra çalışmalarına dayanan bir eğitim modelini benimsediğini belirtmiştir. $\mathrm{Bu}$ verilere göre ders işleyişinde katılımcıların \%91,7'si $(\mathrm{n}=22)$ ders işleyişinde tek partili çalışmalara yer vermekte iken \%62,5'i $(\mathrm{n}=15)$ çok partili çalışmalara yer vermektedir. Bu bulgular doğrultusunda tek partili ve çok partili çalışmaların toplu icra eğitiminde yaygın olarak kullanıldığı tespit edilmiştir.

Toplu icra eğitimini etkileyen faktörlerden olduğunu öngördüğümüz yerel toplu icra geleneklerinin eğitim sürecinde ne denli etkisi olduğunu ölçmeye yönelik olarak katılımcılara "Türk halk müziği toplu icra derslerinde geçilen eserlerin ait olduğu yörelerdeki toplu icra geleneğini (sıra gecesi, yaren sohbetleri, oturak alemleri, kürsübaşı faslı vs.) ve üslubunu ne ölçüde dikkate alıyorsunuz?" sorusu yöneltilmiş ve verilen cevaplar Şekil 4'teki grafikte belirtilmiştir. 


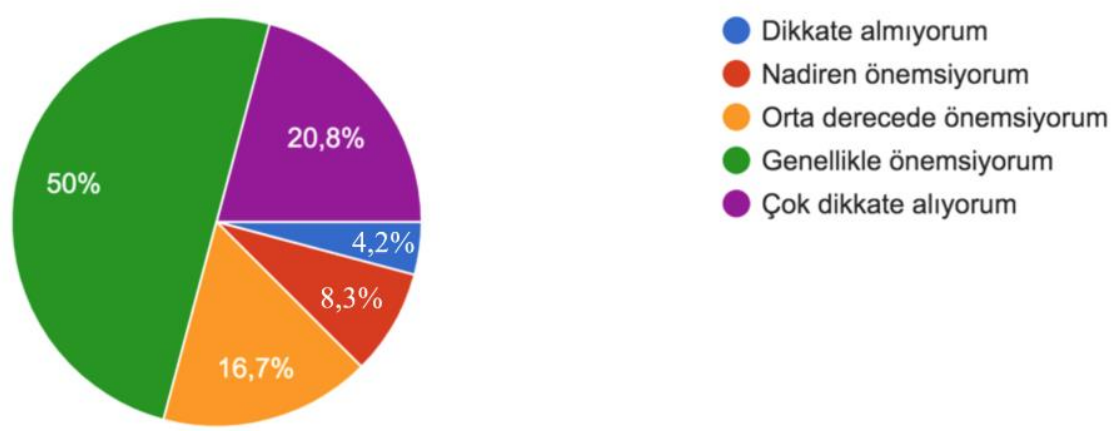

Şekii 4: "Türk halk müziği Toplu icra derslerinde geçilen eserlerin ait olduğu yörelerdeki toplu icra geleneğini (sıra gecesi, yaren sohbetleri, oturak alemleri, kürsübaşı faslı vs.) ve üslubunu ne ölçüde dikkate alıyorsunuz?" sorusuna verilen cevapların grafik üzerinde gösterimi

Elde edilen bulgulara göre katılımcılar toplu icra derslerinde geçtikleri eserlerin ait olduğu yörelerde var olan toplu icra geleneğini büyük ölçüde önemsediklerini beyan etmişlerdir. [\%50 $(n=12)$ genellikle önemsiyorum, \%20,8 $(n=5)$ çok dikkate alıyorum, \%16,7 $(n=4)$ orta derecede önemsiyorum, \%8,3 ( $\mathrm{n}=2)$ nadiren önemsiyorum ve \%4,2 (n=1) dikkate almıyorum].

Çok partili eserleri toplu icra eğitimi içerisinde kullandığını beyan eden katılımcıların ( $\mathrm{n}=15)$ kaç partili eserleri ne sıklıkta derslerde işlediğini tespit etmeye yönelik "Çok partili toplu icra çalışmalarında hangi tür eserleri ne sıklıkta çalıştırmayı tercih ediyorsunuz?" sorusu sorulmuştur. Bu soruya verilen yanıtlar Tablo 2'de özetlenmiştir.

Tablo 2: "Çok partili toplu icra çalışmalarında hangi tür eserleri ne sıklıkta çalıştırmayı tercih ediyorsunuz?" sorusuna verilen cevaplar

\begin{tabular}{|c|c|c|c|c|c|c|c|c|}
\hline & & Hiç & Nadiren & $\begin{array}{l}\text { Orta } \\
\text { Siklıkta }\end{array}$ & $\begin{array}{l}\text { Genelli } \\
\text { kle }\end{array}$ & Çok Sık & $\begin{array}{l}\text { Topla } \\
\text { m }\end{array}$ & $\begin{array}{l}\text { Ağırlıklı } \\
\text { Ortalama }\end{array}$ \\
\hline \multirow[t]{2}{*}{ İki Partili Eserleri } & $\mathrm{n}$ & 0 & 3 & 7 & 1 & 4 & 15 & $\% 60,0$ \\
\hline & $\%$ & $\% 0,0$ & $\% 20,0$ & $\% 46,7$ & $\% 6,7$ & $\% 26,7$ & $\% 100$ & \\
\hline \multirow[t]{2}{*}{ Üç Partili Eserleri } & $\mathrm{n}$ & 1 & 7 & 6 & 1 & 0 & 15 & $\% 36,7$ \\
\hline & $\%$ & $\% 6,7$ & $\% 46,7$ & $\% 40,0$ & $\% 6,7$ & $\% 0,0$ & $\% 100$ & \\
\hline \multirow[t]{2}{*}{ Dört Partili Eserleri } & $\mathrm{n}$ & 4 & 5 & 1 & 4 & 1 & 15 & $\% 38,3$ \\
\hline & $\%$ & $\% 26,7$ & $\% 33,3$ & $\% 6,7$ & $\% 26,7$ & $\% 6,7$ & $\% 100$ & \\
\hline \multirow[t]{2}{*}{ Beş Partili Eserleri } & $\mathrm{n}$ & 10 & 1 & 2 & 2 & 0 & 15 & $\% 18,3$ \\
\hline & $\%$ & $\% 66,7$ & $\% 6,7$ & $\% 13,3$ & $\% 13,3$ & $\% 0,0$ & $\% 100$ & \\
\hline \multirow{2}{*}{$\begin{array}{l}\text { Altı ve Daha Çok Partili } \\
\text { Eserleri }\end{array}$} & $\mathrm{n}$ & 10 & 1 & 3 & 0 & 1 & 15 & $\% 18,3$ \\
\hline & $\%$ & $\% 66,7$ & $\% 6,7$ & $\% 20,0$ & $\% 0,0$ & $\% 6,7$ & $\% 100$ & \\
\hline
\end{tabular}

$\mathrm{Bu}$ verilerden elde edilen ağırlıklı ortalamalara göre çok partili çalışmaları ders işleyişinde kullanan katılımcıların ağırlıkla iki partili çalışmaları tercih ettiği $(\% 60,0)$ ve belirli aralıklarla dört partili $(\% 38,3)$ ve üç partili $(\% 36,7)$ eserleri çalıştırdıklarını beyan etmişlerdir. Beş partili $(\% 18,3)$, altı ve daha çok partili eserlerin $(\% 18,3)$ katılımcılar arasında nadiren tercih edildiği görülmektedir. 


\section{Ĕgitim Materyali ve Repertuvar Tercihi}

Ders işlenişi içerisinde çalışılacak eserlerin kim(ler) tarafından belirlendiğini tespit etmeye yönelik olarak sorulan "Kurumunuzda Türk halk müziği toplu icra derslerinde repertuvar tercihi nasıl yapılıyor?" sorusu çoktan seçmeli ve açık uçlu (diğer vs. varsa belirtiniz) olarak sorulmuş ve bu soruya katılımcıların \%58,3'ü $(n=14)$ eğitmen(ler) tarafından, \%37,5'i ise $(n=9)$ müzakere yoluyla (eğitmenler ve öğrencilerin uzlaşması ile), cevabını vermiştir. ${ }^{8}$

Ders işleyişinde kullanılan eğitim materyalini belirlemeye yönelik "Türk halk müziği toplu icra derslerinde eğitim materyali olarak hangi kaynaklardan ne sıklıkta faydalanıyorsunuz?" sorusuna katılımcıların verdiği yanıtlar Tablo 3 'te özetlenmiştir.

Tablo 3: T.H.M. Toplu İcra İçerikli Derslerde Kullanılan Eğitim Materyaline Yönelik Eğitimci

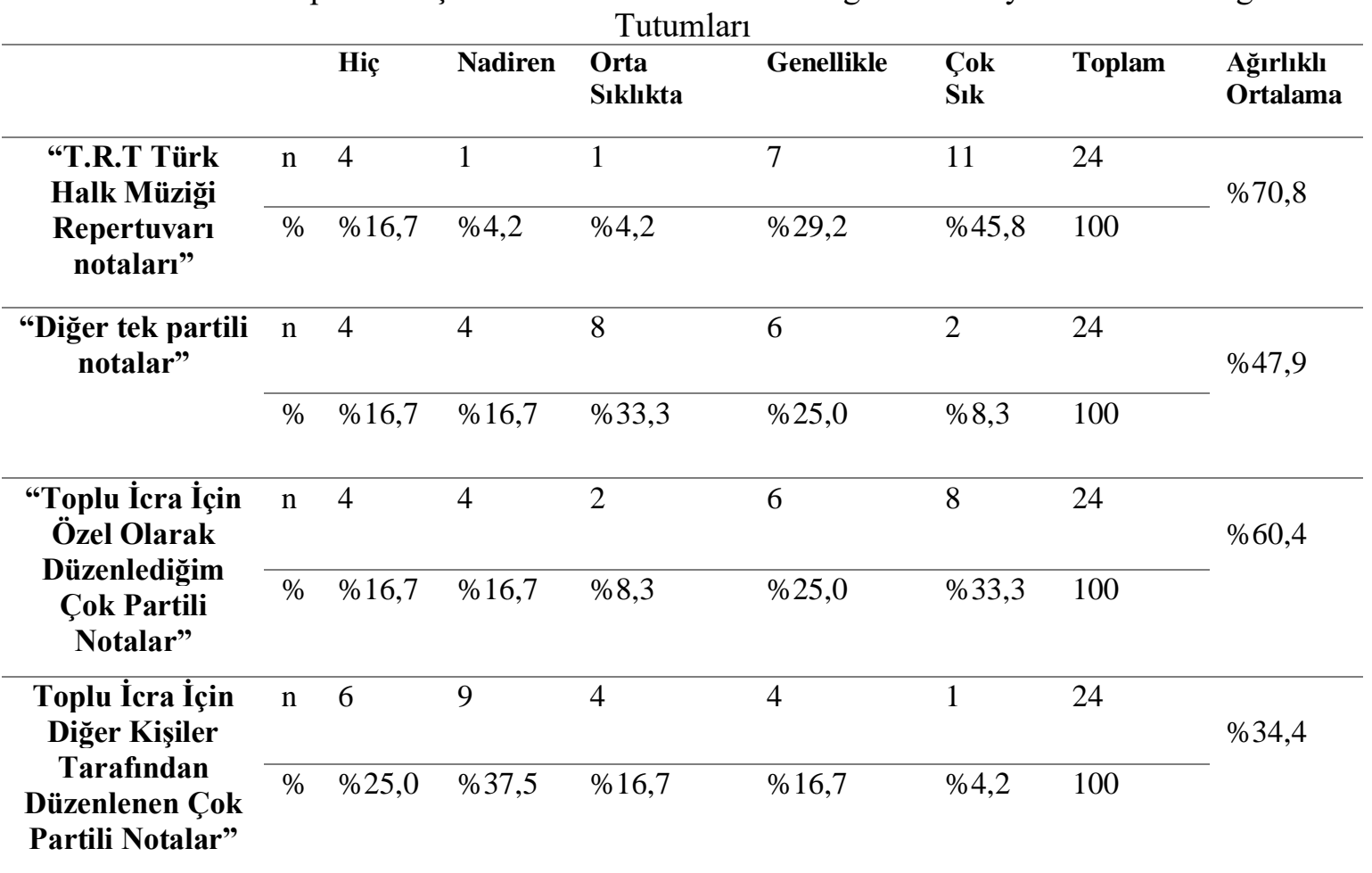

Elde edilen bulgulardan edinilen ağırlıklı ortalamalara göre; toplu icra derslerinde tek partili çalışmaların T.R.T Türk halk müziği repertuvar notaları ile $(\% 70,8)$, çok partili çalışmaların ise öğretim elemanlarının çalıştırdığı topluluk için özel olarak düzenlediği notalardan $(\% 60,4)$ oluştuğu gözlemlenmektedir.

Katılımcılara, derslerde kullandıkları eğitim materyallerini ne ölçüde yeterli bulduklarını ölçmeye yönelik "Türk halk müziği toplu icra derslerinde kullanılan eğitim materyallerini yeterli buluyor musunuz?" sorusu yöneltilmiş olup bu soruya katılımcıların $\% 87,5^{\prime} \mathrm{i}(\mathrm{n}=21)$ eğitim materyallerini yeterli bulmuyorum, $\% 12,5^{\prime} \mathrm{i}(\mathrm{n}=3)^{9}$ eğitim materyallerini yeterli buluyorum şeklinde

\footnotetext{
${ }^{8}$ Şıklar arasında yer alan "öğrenciler tarafından" hiçbir katılımcı tarafından işaretlenmemiş bir seçenektir. Bir $(\mathrm{n}=1)$ katılımc1 "repertuvar seçimini dersin o dönemde vermesi gereken kazanımlara göre seçiyorum" şeklinde belirtmiştir. ${ }^{9}$ Eğitim materyallerini yeterli bulan 3 ögretim elemanının daha önce bahsi geçen "ne tür bir eğitim modeli uyguluyorsunuz" sorusuna 2'si tek partili eğitim modeli cevabını vermiş olup eğitim materyali olarak TRT Türk halk müziği repertuvarını "çok sık" kullandığını belirtmiştir. 1 kişi ise çok partili eğitim modelinde 2 partili çalışmaları orta sıklıkta 3 partili çalışmaları nadiren çalıştırdığını 3' den çok partili çalışmaları ise hiç çalıştırmadığını beyan etmiş ve TRT Türk halk müziği repertuvarını "genellikle" kullandığını belirtmiştir.
} 
beyanda bulunmuştur. $\mathrm{Bu}$ sorudan elde edilen verilere göre katılımcıların bir önceki soruda kullandıklarını beyan ettikleri eğitim materyallerini yeterli bulmadıkları tespit edilmiştir.

Eğitim materyallerini yeterli bulmayan 21 öğretim elemanına yöneltilen; "Eğitim materyalleri açısından yeterli bulmadığınız olası unsurlar ve bu problemlerle karşılaşma sıklığınızı belirtiniz?" Çoktan seçmeli onay kutusu sorusuna verilen yanıtlar aşağıdaki Tablo 4'te özetlenmiştir.

Tablo 4: "Eğitim Materyalleri Açısından Yeterli Bulmadığınız Olası Unsurlar ve Bu Problemlerle Karşılaşma Sıklığınızı Belirtiniz?” Sorusuna Verilen Cevaplar

\begin{tabular}{|c|c|c|c|c|c|c|c|c|}
\hline & & Hiç & Nadiren & $\begin{array}{c}\text { Orta } \\
\text { Sıklıkta }\end{array}$ & Genellikle & Çok Sık & Toplam & $\begin{array}{c}\text { Ağırlıklı } \\
\text { Ortalama }\end{array}$ \\
\hline \multirow{2}{*}{$\begin{array}{c}\text { "Toplu icraya yönelik } \\
\text { eğitim metodu } \\
\text { eksikliğinden } \\
\text { kaynaklanan } \\
\text { problemlere" }\end{array}$} & $\mathrm{n}$ & 0 & 0 & 3 & 9 & 9 & 21 & \multirow{2}{*}{$\% 82,1$} \\
\hline & $\%$ & $\% 0,0$ & $\% 0,0$ & $\% 14,3$ & $\% 42,9$ & $\% 42,9$ & $\% 100$ & \\
\hline \multirow{2}{*}{$\begin{array}{c}\text { "Farklı seviyelerde } \\
\text { icracılar için eğitim } \\
\text { materyalleri } \\
\text { eksikliğinden } \\
\text { kaynaklanan } \\
\text { problemlere" }\end{array}$} & $\mathrm{n}$ & 0 & 0 & 1 & 9 & 11 & 21 & \multirow{2}{*}{$\% 86,9$} \\
\hline & $\%$ & $\% 0,0$ & $\% 0,0$ & $\% 4,8$ & $\% 42,9$ & $\% 52,4$ & $\% 100$ & \\
\hline \multirow{2}{*}{$\begin{array}{c}\text { "İcrayı yansitmayan } \\
\text { notalardan } \\
\text { kaynaklanan } \\
\text { problemlere" }\end{array}$} & $\mathrm{n}$ & 0 & 0 & 1 & 8 & 12 & 21 & \multirow{2}{*}{$\% 88,1$} \\
\hline & $\%$ & $\% 0,0$ & $\% 0,0$ & $\% 4,8$ & $\% 38,1$ & $\% 57,1$ & $\% 100$ & \\
\hline \multirow{2}{*}{$\begin{array}{c}\text { “Çok partili Türk } \\
\text { halk müziği } \\
\text { düzenlemelerinin } \\
\text { eksikliğinden } \\
\text { kaynaklanan } \\
\text { problemlere" }\end{array}$} & $\mathrm{n}$ & 1 & 1 & 6 & 6 & 7 & 21 & \multirow{2}{*}{$\% 70,2$} \\
\hline & $\%$ & $\% 4,8$ & $\% 4,8$ & $\% 28,6$ & $\% 28,6$ & $\% 33,3$ & $\% 100$ & \\
\hline
\end{tabular}

Tablo 4'te görüldüğü üzere araştırmaya katılan katılımcıların eğitim materyalleri açısından yeterli bulunmayan olası şıklarda verilen tüm problemlerle yüksek bir oranda karşılaştığı tespit edilmiştir.

\section{Çalışılan Topluluk Biçimleri}

Türk halk müziği toplu icra derslerinde çalışılan topluluk biçimlerinin kim(ler) tarafından belirlendiğini tespit etmeye yönelik "Türk halk müziği toplu icra derslerinde oluşturulan topluluk üyeleri ne şekilde belirleniyor?” sorusu katılımcılara yöneltilmiş̧ir. Bu sorudaki şıklar, a-) Eğitmen(ler) tarafından, b-) Öğrenci(ler) tarafindan, c-) Müzakere yoluyla (Eğitmenler ve Öğrenciler) d-) Diğer (varsa belirtiniz) şeklindedir. Bu soruya katılımcılar tarafindan verilen cevapların dağılımı ise şu şekildedir: \%54,2'si (n=13) eğitmenler tarafından, \%25,0’i $(n=6)$ hiç kimse tarafindan (dersi alan tüm öğrencilerin tek bir topluluk altında çalışma durumu), \%12,5'i (n=3) müzakere yoluyla (öğrenci-öğretmen), \%8,3’ü (n=2) öğrenciler tarafindan.

Türk halk müziği toplu icra derslerinde çalışılan topluluk biçimlerinden hangi topluluk biçimi ile ne sıklıkta çalışıldığını tespit etmeye yönelik "Türk halk müziği toplu icra derslerinde hangi topluluk biçimleri ile ne sıklıkta çalışıyorsunuz?” sorusu katılımcılara yöneltilmiştir. Katılımciların verdikleri yanıtlar Tablo 5 'te özetlenmiştir 
Tablo 5'te görüldüğü üzere, halk müziği çalgılarından oluşan geniş katılımlı Türk halk müziği orkestrası ağırlıkla çalışılan topluluk biçimi olarak görülmektedir (Ağırlıklı ortalama \%73). Türk halk müziği toplu icra derslerinde yoğun bir şekilde çalışılan topluluk biçimini ise 2,3,4 kişilik küçük çalgı gruplarının oluşturduğu görülmektedir (Ağırlıklı ortalama \%61).

Tablo 5: "Türk halk müziği toplu icra derslerinde hangi topluluk biçimleri ile ne sıklıkta çalışıyorsunuz?" sorusuna verilen cevaplar

\begin{tabular}{|c|c|c|c|c|c|c|c|c|}
\hline & & Hiç & Nadiren & $\begin{array}{l}\text { Orta } \\
\text { Sıklıkta }\end{array}$ & Genellikle & Çok Sık & Toplam & $\begin{array}{l}\text { A ğırlıklı } \\
\text { Ortalama }\end{array}$ \\
\hline \multirow{2}{*}{$\begin{array}{c}\text { İki, üç, dört kişilik çalgı } \\
\text { toplulukları }\end{array}$} & $\mathrm{n}$ & 2 & 4 & 8 & 3 & 7 & 24 & $\% 59,4$ \\
\hline & & $\% 8,3$ & $\% 16,7$ & $\% 33,3$ & $\% 12,5$ & $\% 29,2$ & $\% 100$ & \\
\hline \multirow[t]{2}{*}{ T.H.M. orkestrası } & $\mathrm{n}$ & 0 & 2 & 7 & 7 & 8 & 24 & $\% 71,9$ \\
\hline & $\%$ & $\% 0,0$ & $\% 8,3$ & $\% 29,2$ & $\% 29,2$ & $\% 33,3$ & $\% 100$ & \\
\hline $\begin{array}{l}\text { Alan dışı çalgıların } \\
\text { (flüt, gitar, bas vs.) }\end{array}$ & $\mathrm{n}$ & 10 & 3 & 7 & 2 & 2 & 24 & $\% 32,3$ \\
\hline $\begin{array}{c}\text { katılımı ile desteklenen } \\
\text { T.H.M. orkestrası }\end{array}$ & $\%$ & $\% 41,7$ & $\% 12,5$ & $\% 29,2$ & $\% 8,3$ & $\% 8,3$ & $\% 100$ & \\
\hline
\end{tabular}

Ders içerisinde oluşturulan T.H.M. orkestrası ile çalışan katılımcılara $(n=24)$, çalışılan T.H.M. orkestrasının hangi müzik türüne ait çalgılardan oluştuğunu tespit etmeye yönelik "Ders içerisinde çalıştığınız T.H.M Orkestrası aşağıdaki yapılardan hangisidir?" sorusu katılımcılara yöneltilmiştir. Bu soruya verilen yanttlar Şekil 5'te grafikte özetlenmiştir.

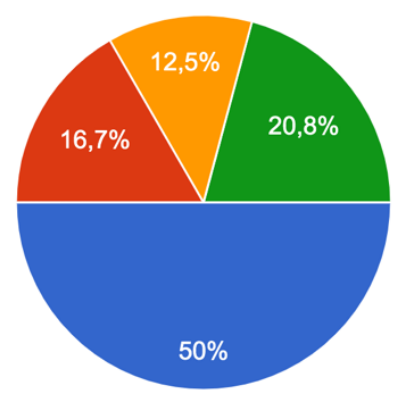

Yalnızca halk müziği çalgılarından oluşan T.H.M orkestrası

İnce sazlarla desteklenen T.H.M orkestarsı

Batı müziği çalgılarıyla desteklenen T.H.M orkestrası

Batı müziği çalgıları ve ince sazlarla desteklenen T.H.M orkestrası

Şekil 5: "Ders İçerisinde Çalıştığınız T.H.M Orkestrası Aşağıdaki Yapılardan Hangisidir" Sorusuna Verilen Cevapların Grafik Üzerinde Gösterimi

Ders içerisinde oluşturulan küçük çalgı toplulukları ile çalışan katılımcılara $(n=22)$, çalışılan küçük çalgı grubunun içeriğini tespit etmeye yönelik "Ders içerisinde çalıştığınız 2,3,4 kişilik çalgı toplulukları hangi çalgılardan oluşmaktadır” sorusu yöneltilmiştir. Bu soruya verilen yanıtlardan elde edilen verilere göre soruya cevap verenlerin $\% 62,5^{\prime} \mathrm{i}(\mathrm{n}=15)$ yalnızca saz/bağlamalardan, $\% 62,5$ 'i (n=15) saz/bağlama(lar) ve üflemeli/yaylı çalgılardan, \%29,2'si (n=7) saz/bağlama(lar) ve vurmalı çalgılardan, \%12,5'i (n=2) üflemeli, yaylı ve vurmalı çalgılardan, \%8,3'ü $(n=2)$ üflemeli ve yaylı çalgılardan, \%4,1'i (n=1) saz/bağlama(lar), üflemeli/yaylı çalgılar ve vurmalı çalgılardan oluşan küçük çalgı topluluklarıyla çalıştıklarını beyan etmişlerdir.

Toplu icra ders ortamının nasıl olması gerektiğine dair katılımcılara "Verimli bir ders ortamının sağlanabilmesi için Türk halk müziği icra topluluğunu kaç kişi oluşturmalıdır?" sorusu yöneltilmiştir. Katılımcıların \%41,7'si $(n=10)$ 4-8 kişiden, \%29,2'si $(n=7)$ 8-14 kişiden, $\% 12,5$ 'i (n=3) 14-20 kişiden, \%4,2'si (n=1) 30 kişiden, \%4,2'si (n=1) 50 kişiden, geriye kalan 
\%8,3'ü ( $\mathrm{n}=2)$ ise "öğrencilerin seviyeleri” ve "içinde bulunulan kurumun eğitim anlayışının beklentisi(hedefleri)" doğrultusunda sayı değişebilir cevaplarını beyan etmiştir.

Görüldüğü üzere, toplu icra çalışmalarında saz/bağlama grupları icra içerisinde ağırlıkla yer almaktadır. $\mathrm{Bu}$ doğrultuda katılımcılara "Sizce aşağıdaki bağlama topluluklarından hangisi/hangileri Türk halk müziği toplu icra dersleri için uygun bir topluluk biçimi olabilir?" sorusu yönetilmiştir. Bu soruya ait olan şıklar şu şekilde sıralanmaktadır: a-) İki bağlamalı b-) Üç bağlamalı, c-) Dört bağlamalı, d-) Beş bağlamalı d-) Altı bağlamalı, e-) Diğer (varsa belirtiniz). (Katılımcılara birden fazla şıkkı işaretleme imkânı sunulmuştur).

Katılımciların \%60'1 (n=12) dört bağlamalı, \%44'ü $(n=9)$ altı bağlamalı, \%40’1 $(n=7)$ üç bağlamalı, \%24'ü $(n=4)$ beş bağlamalı topluluk ile çalışmanın uygun olduğunu belirtmiş; bir katılımc1 "Türk halk müziğinin, güzel sanatlar sistemi kapsamında yer alması amaçlanarak bugün bildiğimiz haline özgü yapılanma sürecine ve hedeflere sahip olduğu göz önüne alınırsa, oluşturulacak bağlama topluluğunun sayı sınırlaması konusunda esnek olduğunu düşünüyorum", bir katılımcı "Hepsi ayrı icra dinamiklerine sahip birlikteliklerdir. Mümkünse tamamı tecrübe edilmelidir" şeklinde fikirlerini beyan etmiş; diğer bir katılımcı ise ideal bağlama topluluk biçiminin "altı ve on bağlama" arasında olması gerektiğini belirtmiştir.

Katılımcılara saz/bağlama grupları içerisinde tel düzenlerinin (akort sistemlerinin) ne ağırlıkta kullanıldığını tespit etmeye yönelik "Toplu icra çalışmalarındaki bağlama icralarında, aşağıdaki akort sistemleri içerisinde hangilerini ne sıklıkta kullanıyorsunuz?" sorusu yöneltilmiş ve bu soruya verilen yanıtlar Tablo 6'da özetlenmiştir

Tablo 6: "Toplu icra çalışmalarındaki bağlama icralarında, aşağıdaki akort sistemleri içerisinde hangilerini ne sıklıkta kullanıyorsunuz?" sorusuna verilen cevaplar

\begin{tabular}{|c|c|c|c|c|c|c|c|c|}
\hline & & Hiç & Nadiren & $\begin{array}{l}\text { Orta } \\
\text { Sıklıkta }\end{array}$ & Genellikle & Çok Sık & Toplam & $\begin{array}{l}\text { Ağırlıklı } \\
\text { Ortalama }\end{array}$ \\
\hline \multirow[t]{2}{*}{ Bozuk Düzen } & $\mathrm{n}$ & 0 & 0 & 1 & 9 & 14 & 24 & $\% 88,5$ \\
\hline & $\%$ & $\% 0,0$ & $\% 0,0$ & $\% 4,2$ & $\% 37,5$ & $\% 58,3$ & $\% 100$ & \\
\hline \multirow[t]{2}{*}{ Bağlama Düzeni } & $\mathrm{n}$ & 1 & 2 & 7 & 10 & 4 & 24 & $\% 64,6$ \\
\hline & $\%$ & $\% 4,2$ & $\% 8,3$ & $\% 29,2$ & $\% 41,7$ & $\% 16,7$ & $\% 100$ & \\
\hline \multirow[t]{2}{*}{ Fidayda Düzeni } & $\mathrm{n}$ & 1 & 16 & 6 & 1 & 0 & 24 & $\% 32$ \\
\hline & $\%$ & $\% 4,2$ & $\% 66,7$ & $\% 25,0$ & $\% 4,2$ & $\% 0,0$ & $\% 100$ & \\
\hline \multirow[t]{2}{*}{ Misket Düzeni } & $\mathrm{n}$ & 3 & 10 & 11 & 0 & 0 & 24 & $\% 33$ \\
\hline & $\%$ & $\% 12,5$ & $\% 41,7$ & $\% 45,8$ & $\% 0,0$ & $\% 0,0$ & $\% 100$ & \\
\hline \multirow[t]{2}{*}{ Müstezat Düzeni } & $\mathrm{n}$ & 3 & 14 & 6 & 1 & 0 & 24 & $\% 30$ \\
\hline & $\%$ & $\% 12,5$ & $\% 58,3$ & $\% 25,0$ & $\% 4,2$ & $\% 0,0$ & $\% 100$ & \\
\hline \multirow[t]{2}{*}{ Do Müstezat Düzeni } & $\mathrm{n}$ & 3 & 13 & 7 & 1 & 0 & 24 & $\% 31,3$ \\
\hline & $\%$ & $\% 12,5$ & $\% 54,2$ & $\% 29,2$ & $\% 4,2$ & $\% 0,0$ & $\% 100$ & \\
\hline \multirow[t]{2}{*}{ Segâh Düzeni } & $\mathrm{n}$ & 3 & 16 & 5 & 0 & 0 & 24 & $\% 27,1$ \\
\hline & $\%$ & $\% 12,5$ & $\% 66,7$ & $\% 20,8$ & $\% 0,0$ & $\% 0,0$ & $\% 100$ & \\
\hline
\end{tabular}

Tablo 6'da görüldüğü üzere "Bozuk Düzen" (ağırlıklı ortalama: \%88,5) ve "Bağlama Düzeni” (ağırlıklı ortalama: \%64,6) toplu icra çalışmalarında ağırlıkla kullanılan akort sistemleridir. 


\section{Karşılaşılan Problemlere Dair Görüşler}

Türk halk müziği toplu icra derslerinde yapılan icralarda katılımcıların hangi tür problemlerle karşılaştıklarını tespit etmeye yönelik "Toplu icra çalışmalarında aşağıdaki problemlerden hangileri ile karşılaşıyorsunuz ve karşılaştı̆ğınız problemlerin görülme sıklığı nedir?" sorusu yöneltilmiştir. Bu soruya verilen yanıtlar Tablo 7'de özetlenmiştir.

Tablo 7: "Toplu icra çalışmalarında aşağıdaki problemlerden hangileri ile karşılaşıyorsunuz ve karşılaştığınız problemlerin görülme sıklığı nedir?" sorusuna verilen cevaplar

\begin{tabular}{|c|c|c|c|c|c|c|c|c|}
\hline & & Hiç & Nadiren & $\begin{array}{l}\text { Orta } \\
\text { Siklıkta }\end{array}$ & Genellikle & Çok Sık & Toplam & $\begin{array}{l}\text { Ağırlıklı } \\
\text { Ortalama }\end{array}$ \\
\hline \multirow{2}{*}{$\begin{array}{c}\text { Zamanlama/ } \\
\text { Senkronizasyon } \\
\text { Problemleri }\end{array}$} & $\mathrm{n}$ & 2 & 6 & 9 & 7 & 0 & 24 & \multirow{2}{*}{$\% 46,9$} \\
\hline & $\%$ & $\% 8,3$ & $\% 25,0$ & $\% 37,5$ & $\% 29,2$ & $\% 0,0$ & $\% 100$ & \\
\hline \multirow{2}{*}{$\begin{array}{c}\text { Perde/ } \\
\text { Entonasyon } \\
\text { Problemleri }\end{array}$} & $\mathrm{n}$ & 1 & 4 & 7 & 9 & 3 & 24 & \multirow[b]{2}{*}{$\% 59,4$} \\
\hline & $\%$ & $\% 4,2$ & $\% 16,7$ & $\% 29,2$ & $\% 37,5$ & $\% 12,5$ & $\% 100$ & \\
\hline \multirow{2}{*}{$\begin{array}{c}\text { Gürlük/ Dinamik } \\
\text { Problemleri }\end{array}$} & $\mathrm{n}$ & 1 & 3 & 7 & 9 & 4 & 24 & \multirow[b]{2}{*}{$\% 62,5$} \\
\hline & $\%$ & $\% 4,2$ & $\% 12,5$ & $\% 29,2$ & $\% 37,5$ & $\% 16,7$ & $\% 100$ & \\
\hline \multirow{2}{*}{$\begin{array}{c}\text { Süsleme } \\
\text { Problemleri }\end{array}$} & $\mathrm{n}$ & 1 & 1 & 6 & 9 & 7 & 24 & \multirow[b]{2}{*}{$\% 70,8$} \\
\hline & $\%$ & $\% 4,2$ & $\% 4,2$ & $\% 25,0$ & $\% 37,5$ & $\% 29,2$ & $\% 100$ & \\
\hline
\end{tabular}

Tablo 7'de görüldüğü üzere toplu icra çalışmalarında başlıca karşılaşılan problemlerin ağırlıklı ortalamaları incelendiğinde büyük çoğunluğunu \%70,8'ini Süsleme problemlemlerinin oluşturduğu görülmektedir. Diğer karşılaşan problemler ise Gürlük/Dinamik problemleri (A ğırlıklı ortalama \%62,5), Perde/Entonasyon problemleri (Ağırlıklı ortalama \%59,4) ve Zamanlama/Senkronizasyon problemleri (Ağırlıklı ortalama \%46,9) olduğu öğretim elemanları tarafından beyan edilmiştir.

Çoktan seçmeli onay kutularından elde edilen bulgulara göre öğretim elemanlarına "Sizce Zamanlama/Senkronizasyon problemleri hangi faktör/faktörlerden kaynaklanmaktadır?", "Sizce Perde/Entonasyon Problemleri problemleri hangi faktör/faktörlerden kaynaklanmaktadır?" Sizce topluluk içerisinde gürlük problemleri hangi faktör/faktörlerden kaynaklanmaktadır? "Sizce Nüans/Süsleme Problemleri problemleri hangi faktör/faktörlerden kaynaklanmaktadır?" Soruları farklı sorular olarak yöneltilmiştir. Bu dört soruya ait olan bütün şıklar aynı ve şu şekilde sıralanmaktadır; a-) bireysel icra yeterlilik probleminden b-) orkestra içerisinde duyma dinleme probleminden, c-) deşifre/partisyon okuma yeterlilik probleminden d-) dikkat/konsantrasyon eksikliği probleminden e-) Diğer (varsa belirtiniz). $\mathrm{Bu}$ dört soruya katılımcılar tarafindan verilen yanıtlar Tablo 8'de özetlenmiştir. 
Tablo 8: "Toplu icra çalışmalarında karşılaşılan problemlerin tespitine yönelik sorulan sorulara katılımcilar tarafindan verilen cevaplar" 10

\begin{tabular}{|c|c|c|c|c|c|c|c|c|c|c|}
\hline & \multicolumn{2}{|c|}{$\begin{array}{l}\text { Bireysel İcra } \\
\text { Yeterlilik } \\
\text { Problemleri }\end{array}$} & \multicolumn{2}{|c|}{$\begin{array}{l}\text { İcracıların } \\
\text { Orkestra İçinde } \\
\text { Duyma/Dinleme } \\
\text { Problemi }\end{array}$} & \multicolumn{2}{|c|}{$\begin{array}{l}\text { Deşifre/Partisyon } \\
\text { Okuma Yeterlilik } \\
\text { Problemleri }\end{array}$} & \multicolumn{2}{|c|}{$\begin{array}{l}\text { Dikkat/ } \\
\text { Konsantrasyon } \\
\text { eksikliği } \\
\text { problemleri }\end{array}$} & \multicolumn{2}{|c|}{ Diğer ${ }^{11}$} \\
\hline & $\mathrm{n}$ & $\%$ & $\mathrm{n}$ & $\%$ & $\mathrm{n}$ & $\%$ & $\mathrm{n}$ & $\%$ & $\mathrm{n}$ & $\%$ \\
\hline $\begin{array}{c}1 . \\
\text { Soru }\end{array}$ & 22 & $\% 91,7$ & 18 & $\% 75,0$ & 15 & $\% 62,5$ & 13 & $\% 54,2$ & 2 & $\% 8,3$ \\
\hline $\begin{array}{c}2 . \\
\text { Soru }\end{array}$ & 20 & $\% 83,3$ & 15 & $\% 62,5$ & 3 & $\% 12,5$ & 7 & $\% 29,2$ & 3 & $\% 12,5$ \\
\hline $\begin{array}{c}3 . \\
\text { Soru }\end{array}$ & 17 & $\% 70,8$ & 14 & $\% 58,3$ & 7 & $\% 29,2$ & 15 & $\% 62,5$ & 1 & $\% 4,2$ \\
\hline $\begin{array}{c}4 . \\
\text { Soru }\end{array}$ & 24 & $\% 100,0$ & 10 & $\% 41,7$ & 8 & $\% 33,3$ & 12 & $\% 50,0$ & 1 & $\% 4,2$ \\
\hline
\end{tabular}

\section{Toplu İcra Dersinin Eğitimdeki Ağırlı̆̆ı}

Toplu icra eğitiminin örgün eğitim içerisindeki ağırlığını tespit edebilmek amacıyla katılımcılara "Kurumunuzda, Türk halk müziği toplu icra eğitiminin müfredat içerisindeki haftalık ders saati nedir?" sorusu yöneltilmiştir.

Elde edilen bulgulara göre katılımcılar işledikleri dersin ders programı içerisindeki ders saatini Tablo 9'da görüldüğü şekli ile beyan etmişlerdir.

Tablo 9: Katılımcıların verdiği “T.H.M. Toplu İcra” içerikli derslerin ders programında belirlenmiş saati $^{12}$

\begin{tabular}{lll}
\hline $\begin{array}{l}\text { T.H.M. Toplu İcra Eğitimi İçerikli } \\
\text { Dersin Eğitim Kurumunun Ders } \\
\text { Planlarında Belirtilen Ders Saatleri }\end{array}$ & Katılımcı Sayısı (n) & Katılımcı Yüzdesi (\%) \\
\hline 2 saat & 12 & \\
\hline 3 saat & 2 & 50,0 \\
\hline 4 saat & 11 & 8,3 \\
\hline $\mathbf{5}$ saat & 1 & 45,8 \\
\hline
\end{tabular}

\footnotetext{
${ }^{10}$ Tabloda görülen "1.Soru”, "2. Soru”, “3. Soru”, "4. Soru” ifadeleri daha önce sorulan dört soruyu temsil etmektedir. 1. Soru: "Sizce Zamanlama/Senkronizasyon problemleri hangi faktör/faktörlerden kaynaklanmaktadır?", 2. Soru: "Sizce Perde/Entonasyon Problemleri problemleri hangi faktör/faktörlerden kaynaklanmaktadır?", 3. Soru: "Sizce topluluk içerisinde gürlük problemleri hangi faktör/faktörlerden kaynaklanmaktadır?", 4. Soru: "Sizce Nüans/Süsleme Problemleri problemleri hangi faktör/faktörlerden kaynaklanmaktadır?"

${ }^{11}$ Soruda yer alan diğer (açı uçlu cevap) şıkkını seçen katılımcıların sorulara dair cevapları, 2 katılımcı ( $\left.\mathrm{n}=2\right)$ 1.soru için "Zamanlama senkronizasyon problemleri ile karşılaşmıyorum" ve "metronom ile çalışma eksikliğii”, 3 katılımcı (n=3) 2.soru için "Kullanılan enstrümanların yapımında bir standart olmaması", 1 katılımcı $(n=1)$ 3.soru için "Çalgıların yapısal özelliklerini önemli bir etken olarak görmekteyim”, 1 katılımcı (n=1) 4.soru için " Müzik eserleri içerisinde var olan nota yazım eksikliklerinden dolayı" şeklinde olmuştur.

${ }^{12}$ Bazı programlarda farklı sınıflar içerisinde ders saatinin farklılık göstermesi ve son 5 yıl içinde katılımcıların ders verdi ği kurumlarda ders yapısının değişmesi ihtimali göz önüne alınarak bu soru açık uçlu olarak sorulmuş olup katılımcılara birden fazla yanıt verme imkânı verilmiştir.
} 
Tablo 9'da görüldüğü üzere katılımcıların çoğu (\%84) dersleri haftada 2 saat işlediğini belirtmiştir. Yine büyük bir kısmı (\%52) bu dersin programda haftada 4 saat olarak görüldügünü ve bu şekilde işlendiği belirtmiştir. 2 katılımcı ise (\%8) haftada 3 saat toplu icra dersinin işlendiğini belirtmiştir. 2 katılımeı dersin lisans 2. ve 3. sınıfta 2 saat, lisans 4 . sınıfta 4 saat olarak işlendiğini belirtmiştir. 1 katılımcı ise kurumunda toplu uygulama ( 2 saat) ve orkestra ( 3 saat) dersi şeklinde 2 ayrı toplu icra dersi olduğunu ve toplamda $5(2+3)$ saat ders verdiğini belirtmiştir.

Toplu icra derslerinin müfredat içerisinde ders saat sıklı̆̆ açısından ne düzeyde olması gerektiği üzerine öğretim elemanlarına "Sizce Türk halk müziği toplu icra eğitimi için öğrencilerin ders saati müfredat içerisinde haftalık kaç saat olmalıdır?" sorusu yöneltilmiştir.

Şekil 6'da görüldüğü üzere öğretim elemanlarının \%79,2'si (n=19), haftada 3-4 saat, \%12,5'i $(\mathrm{n}=3)$, haftada 5-6 saat, \%4,2'si $(\mathrm{n}=1)$, haftada 7-8 saat ve \%4,2'si $(\mathrm{n}=1)$, 'beklentiler, hedefler, öğrencinin ve eğitimcinin kapasiteleri gibi değişkenler belirleyici olacaktır" şeklinde cevap vermişlerdir.

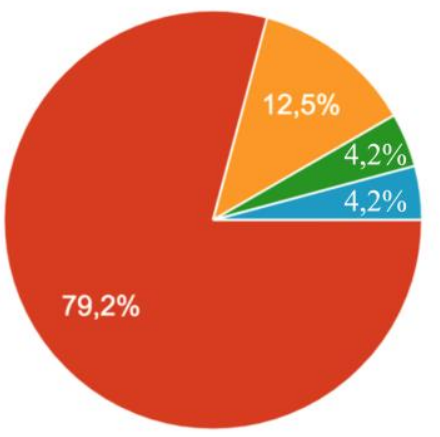

Haftada 1-2 saat

Haftada 3-4 saat

Haftada 5-6 saat

Haftada 7-8 saat

Haftada 9-10 saat

Beklentiler, hedefler, öğrencinin ve eğitimcinin kapasiteleri gibi değişkenler belirleyici olacaktır.

Şekil 6: Sizce Türk halk müziği toplu icra eğitimi için öğrencilerin ders saati müfredat içerisinde haftalık kaç saat olmalıdır?"

Öğrencilerin toplu icra ders sorumluluklarına toplu icra ders saatleri hariç ne kadar çalışması gerektiğine dair öğretim elemanlarına "Sizce Türk halk müziği toplu icra eğitimi için öğrencilerin ders saati dışında haftalık çalışma saati ne kadar olmalıdır?” sorusu yöneltilmiştir. Elde edilen bulgulara göre katılımcıların \%37,5'i $(\mathrm{n}=9)$ haftada 5-6 saat, \%20,8'i $(\mathrm{n}=5)$ haftada 3-4 saat, $\% 16,7$ 'si $(\mathrm{n}=4)$ haftada 7-8 saat, \%8,3'ü $(\mathrm{n}=2)$ haftada 9-10 saat, \%8,3'ü $(\mathrm{n}=2)$ haftada 1-2 saat şeklinde yanıtlamıştır. Benzer şekilde hedefler ve öğrencilerin kapasiteleri ders dışındaki çalışma sürecini belirleyecektir, şeklinde cevap verdiği görülmektedir. Katılımcılardan elde edilen verilerin ortalaması yaklaşık olarak 5 saattir.

\section{Değerlendirmeye İlişkin Sorular}

Öğretim elemanlarının çalıştıkları kurumlar içerisinde toplu icra derslerini nasıl ve hangi unsurlarla değerlendirdiklerini tespit etmek amacıyla "Kurumunuzda Türk halk müziği toplu icra derslerinde değerlendirme kriterleriniz nelerdir?" sorusu yöneltilmiştir. Elde edilen bulgulara göre, ders notu değerlendirmelerini katılımcıların \%58,3'ü $(n=14)$ sinavdaki bireysel ve toplu performansın belli yüzdelerle değerlendirilmesi, \%20,8'i $(n=5)$ sinavda toplu olarak icra edilen performansın değerlendirilmesi, \%12,5'si (n=3) sınavdaki performanslarının ve diğer etkenlerin belli yüzdelerle toplamı olarak değerlendirilmesi, $\% 8,3^{\prime} \ddot{u}(\mathrm{n}=2)$ sinavda bireysel olarak icra edilen performansın değerlendirilmesi şeklinde yaptıklarını beyan etmişlerdir.

Toplu icra derslerinde öğrenci performans değerlendirmelerinin kimler tarafindan yapıldığını tespit edebilmek amacıyla öğretim elemanlarına "Kurumunuzdaki Türk halk müziği toplu icra derslerinde değerlendirmeler kim/kimler tarafindan yapılmaktadır?" sorusu yöneltilmiştir. Katılımcıların \%75'i $(n=18)$ eğitmenlerden oluşan bir jüri tarafından, \%50'si ise $(n=12)$ dersi veren eğitmenler tarafından ders değerlendirmelerinin yapıldığını beyan etmişlerdir. 


\section{Yorumlar ve Öneriler}

Bu çalışmada elde edilen verilerin ışığında, toplu icranın bireysel icra eğitimine katkısının pek çok farklı boyutta ve önemli bir düzeyde olduğunun düşünüldüğ̈̈, toplu icraya yönelik eğitim modeli eksikliği başta olmak üzere toplu icra eğitimi esnasında farklı problemlerle karşıllaşıldığı tespit edilmiştir. Öğretim elemanlarından elde edilen veriler doğrultusunda toplu icra uygulamalarına ve eğitimi sürecine dair kişisel yorumlar ve öneriler aşağıda belirtilmiştir.

Katılımcıların derslerde kullandıkları eğitim materyallerinin yüksek bir oranda yetersiz olduğu görüşünü belirtmesi bu alanda yapılması gereken eğitim materyali çalışmalarının ne derece önemli olduğuna dair ipuçları barındırmaktadır. Yapılan tek partili toplu icra çalışmalarında repertuvar tercihi olarak T.R.T Türk halk müziği repertuvarının büyük bir oranda tercih edildiği görülmektedir. T.R.T Türk halk müziği repertuvarındaki notaların icrayı yansıtma hususunda pek çok bakımdan yetersiz kaldığ 1 (Parlak, 2016; 213-214) ve bu konunun akademik anlamda pek çok çalışmada vurgulandığ bilinmektedir. Katılımcılardan elde edilen "icrayı yansıtmayan notaların" toplu icra esnasında yoğunlukla problemlere sebep olduğu verisi de bu düşünceyi destekler niteliktedir. $\mathrm{Bu}$ tür notalar toplu icra esnasında özellikle süslemelerin düzgün bir şekilde icra edilememesi, nüans birlikteliğinin sağlanamaması gibi sorunlara neden olmaktadır. Elde edilen bulgulara göre bu gibi sorunların bireysel icra açısından da problem teşkil ettiği düşünüldügünde çalgı eğitiminde eğitim materyali olarak kullanılan notaların tamamının icrayı yansıtma kapasitesinin yüksek olması gerektiği düşünülmektedir. Bu bakımdan akademiler bünyesinde yapılacak olan çalışmalarda bu konunun dikkate alınması ve eğitim içerisinde kullanılacak materyallerin "yöresel üsluplar", "kişisel tavırlar" ve "yorum" çerçevesinde şekillenen farklı "edisyonlar" olarak hazırlanması bu sorunun çözümünde önemli katkı sağlayacaktır.

Türk halk müziği toplu icra eğitimini etkileyen faktörler içerisinde olan geleneksel toplu icra üsluplarının toplu icra eğitiminde yüksek oranda önemsendiği ancak yöresel toplu icra niteliklerini müzikal açıdan değerlendiren yeterince araştırma yapılmadığı tespit edilmiştir. Bu derece önem atfedilen bir konuda yeterince akademik çalışma yapılmamış olması son derece düşündürücüdür. $\mathrm{Bu}$ bulgulara dayanarak öncelikle yöresel üslupların toplu icra özelinde net olarak ortaya çıkarılması gerekmekte olduğu sonucuna varılmıştır. Böylece Anadolu'nun yöresel toplu icra üslubu haritası belirlenebilecek, bu haritanın ortaya koyacağı nitelikler doğrultusunda toplu icra eğitimine bu üslupların nasıl aktarılabileceği hususunda çalışmalar yapılabilecektir.

Türk Halk Müziği toplu icra eğitiminin içeriğinde bulunan önemli bir eğitim yöntemi de çok partili eğitime dayanan çalışmalardır. Çok partili toplu icra şeklinin uygulandığı derslerde, eğitim materyallerinin ağırlıkla dersi veren eğitmenler tarafından hazırlandığı görülmektedir. Sonuç olarak, çok partili Türk halk müziği toplu icra çalışmalarına tüm eğitim camiasının ihtiyacı olduğu ortaya çıkmaktadır. Kanımızca, bu ihtiyacı karşılamak amacıyla T.H.M. eğitimi alan kişilerin T.H.M. toplu icra uygulamalarına yönelik belirli düzeyde kompozisyon eğitimi alması nitelikli ve zengin toplu icra materyallerinin geliştirilmesi açısından önemli görülmektedir. Katılımcıların ihtiyaçları düşünüldüğünde, saz/bağlama grupları başta olmak üzere farklı çalg1 grubu kombinasyonlarına kolayca uyarlanabilecek özellikle iki partili, üç partili ve dört partili eğitim materyalleri başta olmak üzere çok partili eğitim materyallerinin sayısının ve niteliğinin arttırılması gerekmektedir. Ayrıca, farklı düzenlemeciler tarafından halk müziği çalgıları için düzenlenmiş türkülere ve özgün kompozisyonlara ait çok partili bir repertuvarın da oluşturulması son derece elzemdir. Tıpkı tek partili halk müziği repertuvarının bir kurumsal yap1 altında toplandığı gibi (T.R.T T.H.M. Repertuvarı), halk çalgıları ve vokal partisyonlarından sözlü ya da çalgısal çok partili eserlerden oluşacak bir külliyatında akademik ve kurumsal yapılar bünyesinde oluşturulacak bir merkez içerisinde toplanması ve topluma açık olarak sergilenmesi, çalışmaların doğru kaynaklar vasıtasıyla daha çok kişiye ulaşabilmesi açısından önem arz etmektedir. 
Toplu icra çalışmalarında süsleme nüans, entonasyon ve senkronizasyon problemleri başta olmak üzere pek çok problemle karşılaşıldığı görülmektedir. Deşifre/partisyon okuma eksikliğinden kaynaklanan problemlerin özellikle zamanlama/senkronizasyon açısından toplu icrada problemlere sebep olduğu düşünülmekte olup bu bakımdan eğitim sistemi içerisinde partisyon çalmaya yönelik derslerin ağırlığının arttırılması toplu icra derslerini olumlu yönde etkileyecek bir faktör olarak düşünülmektedir. Ayrıca, orkestra içerisinde duyma dinleme problemlerinin, başta zamanlama/senkronizasyon problemi olmak üzere birçok probleme yol açtığı düşünülmekte olduğu bu çalışmada tespit edilen bulgulardan birisidir. Bu bakımdan özellikle Türk halk müziği orkestrasının içeriğine, orkestra içerisindeki çalgı gruplarının ideal dağılımına, çalgıların teknik özelliklerine göre yerleşim düzenine ve ses ekipmanları ile toplu icra yapılması söz konusu olduğu durumlar özelinde ekipmanların yerleşim düzeni ve niteliği açısından standart ölçülerin belirlenmesine yönelik çalışmalar yapılması da büyük önem arz etmektedir.

$\mathrm{Bu}$ araştırmada elde edilen bulgulara göre toplu icra içerisinde nüans birlikteliğini sağlamaya yönelik karşılaşılan problemlerin altında yatan en büyük sebeplerden birisinin dikkat konsantrasyon eksikliği olduğu düşünüldüğü tespit edilmiştir. $\mathrm{Bu}$ sorunun temelinde özellikle bireysel icra eğitiminde dinamiklerin çalışılmasına yönelik yeterli bir ön çalışma yapılmıyor olması ve bunun sonucunda öğrencilerin bu konuya dair bir alışkanlık kazanamaması yatıyor olabilir. Bu tür çalışmalar için bireysel icra ve toplu icrayı düşünülerek üretilmiş birbirinden farklı dinamik/nüans işaretleri ile donatılmış alıştırmaların eğitim sistemi içerisinde yer alması gerektiği düşünülmektedir.

Eğitimcilerin toplu icra çalışmalarında karşılaştıkları bir diğer problem ise toplu icra dersini alan öğrenciler arasındaki icra düzeyinin farklı olmasıdır. Bu konu toplu icra dersinin ötesinde, tüm müzik eğitimini de etkileyen başlıca unsurlardan birisidir. Ders geçme sistemi içerisindeki katılaşmış müfredat anlayışı farklı icra seviyelerindeki öğrencilerin "sınıf" uygulaması çerçevesinde aynı düzeydeki bir kategoride eğitim görmelerine sebep olmaktadır. Bu bakımdan icra seviyesine dayalı eğitimsel yöntemlerin benimsenmesi ve aynı icra seviyesindeki öğrencilerin bulundukları sınıftan bağımsız olarak toplu icra derslerini bir arada yapacağı bir sistemin tasarlanması ülke müzik eğitimi açısından en uygun eğitim yöntemi olacaktır. Yurtdışında birçok kurumda kullanılan "derece sistemi” (graded system) bu açıdan önemli bir örnek teşkil etmektedir.

Katılımcıların büyük bir çoğunluğu derslerin tamamen halk çalgılarından oluşan T.H.M. Orkestrası şeklinde bir toplulukla işlendiğini belirtmekte; kimi zaman Batı Müziği ya da Klasik Türk müziği çalgıları ile eklemlenen T.H.M. Orkestrasının da ders işleyişinde yer alan bir topluluk biçimi olduğunu belirtmişlerdir. Katılımcıların çoğunluğu verimli bir ders ortamının sağlanabilmesi için en ideal orkestranın 4-8 kişi arasında olduğunu belirtmiş, katılımcıların verileri doğrultusunda 14 kişiden fazla olan orkestraların genellikle tercih edilmediği görülmüştür. Topluluk içerisinde kişi sayısı arttıkça zamanlama, perde entonasyon, nüans birlikteliği ve süsleme icrası ile ilgili problemlerin yoğunlaştığı göz önünde bulundurulduğunda çalg1 icracısı bakımından ideal halk müziği torkestrasının 4-14 kişi arasında olmasının uygun olduğu düşünülmektedir. Bunun dışında, 2 ile 4 kişiden oluşan küçük topluluklarla yapılan müzik eğitiminin de ağırlığı göz önüne alınarak, bu topluluklara uygun farklı müzikal dokularda daha çok eğitim materyali üretilmesi gerekliliği tespit edilmiştir.

Eğitim kurumları içerisinde şu an yürütülmekte olan Türk halk müziği toplu icra derslerinin çoğunlukla haftada 2 saat ya da 4 saat yürütüldüğü görülmektedir. Eğitimcilerin çoğunluğu ise derslerin haftada en az 3-4 saat olarak yapılanmasının eğitim açısından daha uygun olacağını belirtmiştir. Kanımızca geniş katılımlı T.H.M. orkestrası ile küçük topluluklarla yapılan icra çalışmaları arasında eğitimsel açıdan farklı kazanımlar vardır. Bu açıdan toplam 4-5 saat civarında toplu icra içerikli birden fazla dersin (az sayıda icracı ile toplu uygulama ve çok sayıda icracı ile orkestra şeklinde) eğitim müfredatında yer alması düşüncesi de toplu icra eğitimi açısından faydalı olabilir. 
Toplu icra ders değerlendirme şekli incelendiğinde, öğrencilerin sınavdaki bireysel ve toplu performansının belli yüzdelerle dağılımını dikkate alarak yapılan ders değerlendirmelerinin ve değerlendirmelerin jüri tarafından yapıldığı sınav formatının ağırlıkla tercih edildiği tespit edilmiştir. Kanımızca jüri karşısında yapılan sınavlar daha objektif bir değerlendirme yöntemi olup eğitmenlerin eksikliklerini gözden geçirmesi bakımından da bir firsattır. Ayrıca, yalnızca toplu icranın ya da yalnızca bireysel icranın değerlendirilmesi de objektif ve hakkaniyetli bir değerlendirme olmayacaktır. Bu bakımdan katılımcıların değerlendirme tercihlerinin eğitim yöntemi açısından uygun olduğu düşünülmektedir.

$\mathrm{Bu}$ çalışmada elde edilen veriler 1şığında T.H.M. toplu icra eğitiminde birçok farklı problemin olduğu, bu problemlerin çözümüne yönelik T.H.M. toplu icra eğitimine özgü bir eğitim modeli olmadığ 1 ya da yetersiz eğitim modelleri ile eğitimin yürütüldüğü tespit edilmiștir. Bu konuda ilerleyen süreçte yapılacak araştırmalarda T.H.M. toplu icra eğitimine ve eğitim modellerine yönelik çalışmalar yapılması bir gereklilik olarak karşımızda durmaktadır. Sonuç olarak, geçmişten günümüze farklı üsluplarda toplu icra çalışmaları yapılmış olup bu çalışmalardan elde edilen zengin birikiminin T.H.M'nin toplu icra eğitim modeline nasıl bir içerik, yaklaşım ve müfredatla yansıtılabileceğine dair öneriler şu şekilde sıralandırılmıştır :

1- Oluşturulması öngörülen eğitim modelinin gerekli ihtiyaçları karşılaması bakımından hem tek partili hem de çok partili toplu icra eğitimine katkı vermesi gerekmektedir. Bu bakımdan ihtiyaç duyulan eğitim modelinin farklı müzikal dokuları (monofonik, homofonik, polifonik) gözeterek pedagojik bir şekilde tasarlanması uygun olacaktır.

2- Oluşturulması öngörülen eğitim modelinde tek partili çalışmalar içerisinde yörelerdeki toplu icra geleneklerinden derlenen eserlere, yöresel toplu icra üslubunu gözeterek yer verilmesi ve bu üslupların eğitime sürecinde işlenmesi önemli görülmektedir.

3- Oluşturulması öngörülen eğitim modelinde yer alacak olan çok partili çalışmaların daha çok iki, üç ve dört partili çalışmalar ağırlıkta olmak üzere yapılması uygun görülmektedir.

4- Elde edilen veriler doğrultusunda toplu icra gruplarının oluşumunda iki, üç, dört kişilik küçük çalgı topluluklarının ders işleyişinde önemli bir yer teşkil ettiği tespit edilmiştir. Bu küçük çalgı topluluklarının yapısı incelendiğinde ise topluluğun daha çok saz/bağlama ağırlıklı olduğu, bazı durumlarda saz/bağlama grubuna bir yaylı çalgı, üflemeli çalgı, ya da vurmalı çalgının eşlik etmesi ile grubun yapısının oluştuğu görülmektedir. Tamamen sazlardan/bağlamalardan oluşan topluluklarda 3-6 kişi arası saz/bağlama icracısından oluşan toplulukların eğitimde tercih edildiği; sazdaki/bağlamadaki akort sistemleri içerisinde ise en çok bozuk düzen ve bağlama düzeninin toplu icra çalışmalarında kullanıldığ 1 tespit edilmiştir. Oluşturulması öngörülen eğitim modelinde bu çalg1 topluluğu yapılarının ve düzenlerinin dikkate alınması, farklı çalgı grubu kombinasyonlarına kolayca uyarlanabilecek eğitim materyallerinin arttırılması, modelin toplu icra eğitim pratiğine fayda sağlaması açısından önemli görülmektedir. Ayrıca, toplu icrada icra edilen eserin karakterine göre saz/bağlama çalgısının "bozuk düzen" ve "bağlama düzeni" dışındaki diğer düzenlerde de icra edilmesine yönelik eğitim materyali geliştirilmesi ve uygun ortamın sağlanmas hem toplu icra eğitiminin bireysel icra eğitimini desteklemesi bakımından, hem de sıklıkla kimi çevrelerce dile getirilen bu düzenlerimizin müzik eğitiminin merkezinde yer alması gerektiği idealinin sağlanması bakımından önem teşkil ettiği düşünülmektedir.

5- Oluşturulması öngörülen toplu icra eğitim modeli içerisinde yer alacak tüm notaların bütün icrasal özelliklere dikkat edilerek (nüans, süsleme, teknik) vb. yazılması gerekmektedir. Özellikle süsleme ve nüansla ilgili problemlerle karşılaşılma sıklı̆̆nın yüksek olması bu sorunların çözümüne yönelik eğitim metodu gereksinimini ortaya çıkarmaktadır. Bu tür müzikal öğelerin belirli bir pedagojik yaklaşımla bireysel icra eğitimi içerisinde öğretilmesi toplu icra eğitimi açısından sorunların çözümüne yönelik önemli bir adım olacaktır. Özellikle, bireysel çalg1 eğitiminde süslemelerin belirli ritmik kalıplarla çalıştırılmasına yönelik eğitim materyalinin hazırlanması, başta 
monofonik dokuda yapılan toplu icra biçimi olmak üzere icranın kalitesinin arttırılmasında önemli bir etki yaratacaktır.

6- Oluşturulması öngörülen eğitim modeli bünyesinde birbirinden çok farklı icra seviyelerine yönelik eğitim materyalleri bulunmalı ve bu materyaller model içerisinde zorluk seviyesine göre siralanmalıdir.

\section{Kaynakça}

Akdağ, A. K., \& Derin, U. Y. (2013). Güzel Sanatlar ve Spor Lisesi Bağlama 12.Sinıf Ders Kitabı. Milli Eğitim Bakanlığı Yayınları.

Alpagut, U. (2013). Cumhuriyetin İlk Yıllarında Müzik Eğitiminin Yaygınlaştırılması. Milli Folklor Dergisi(97), 210-230.

Alpyıldız, E. (2012). Yerelden Ulusala Taşınan Müzik Belleği ve Yurttan Sesler. Milli Folklor Dergisi (96), 84-93.

Altınay, F. R. (2011). Geleneksel Müzikte Ses Üretme Bağlamında Türk Halk Müziğinde

Seslendirme. Ege Üniversitesi Devlet Türk Musikisi Konservatuvarı Dergisi (1), 49-59.

https://doi.org/10.31722/konservatuvardergisi.484097

Camgöz, N. (2019). Anadolu Türkülerinin Anadolu Pop- Rock Müzik Türüne Uyarlanmasının Halkbilimsel İncelenmesi. Doktora Tezi, İstanbul Üniversitesi Sosyal Bilimler Enstitüsü.

Coşkun Yamak, S. (2006, Ocak). Türk Halk Müziğinde Oluşturulan Geleneksel Ve Modern Çalgl Topluluklarının Yapısal Analizi, Yüksek Lisans Tezi, Haliç Üniversitesi, Sosyal Bilimler Enstitüsü.

Çalışkan, F. (2018). 1980’lerden Günümüze Performans Pratiğinin Dönüşümü ve Etkileri: Bağlama Çalgısında El İle (Tezenesiz) Çalma Tekniği. Porte Akademik Müzik ve Dans Araştırmaları Dergisi, 17 (17), 1-29.

Çevik, M. (2018). Dilden Tele Türkiye’yi “Bir”leştiren Ses: Yurttan Sesler. Uluslararası Türk Dili Edebiyat ve Çeviri Dergisi, 61, 56-59.

Demir, M. (2017). Gelenek ve Modernite Bağlamında Bir Halk Müziği Topluluğu Olarak "Yurttan Sesler". Turkish Studies, 12(21), 207-224. https://doi.org/10.7827/turkishstudies.12107

Duygulu, M. (2002). Küreselleşme ve Sosyal Değişim Sürecinde, Türk Halk Müziğinde:Kimlik, Tavır, Teknik. Kültür Seksiyon Bildirileri, Kültür Bakanlığı Yayınları.

Ekim, G. (2019). Geçmişten Günümüze Bağlama İle İlgili, Resmi İcra ve Eğitim Kurumundaki Uygulamalar Çerçevesinde Bir Değerlendirme. Turkish Studies, 14(4), 2235-2241. https://doi.org/10.29228/turkishstudies.22505

Erdemir, K. B. (2013, Haziran). Tanburacı Osman Pehlivan'1n Hayat1, İcrâcılığı ve Eserleri. Yüksek Lisans Tezi, İstanbul Teknik Universitesi, Sosyal Bilimler Enstitüsü.

Ersoy, İ. (2014). Türk Halk Müziğinin Yeniden Üretimi/İnşası: Ulusal Kaynaştırma Projesi Olarak "Yurttan Sesler" Topluluğu. International Journal of Human Sciences(11), 932-947. https://doi.org/10.14687/ijhs.v11i2.3057

Markoff, I. (1990-1991). The Ideology of Musical Practice and the Professional Turkish Folk Musician: Tempering the Creative Impulse. Asian Music, 22(1), 129-145. https://doi.org/10.2307/834293 
Öcal, M. (2013). Türk Halk Müziğinde Toplu Çalma Söyleme Geleneği. Folklor/Edebiyat Dergisi, 19(75), 129-158.

Özmenteş, S. (2005). Müzik Eğitiminin Boyutları ve Çalg1 Eğitimi. İnönü Üniversitesi Eğitim Fakültesi Dergisi, 6(9), 89-98.

Özbek, M., Sun, M., Bayraktar, E., Tuğcular, E., Önder, B. (1989) Türk Halk Müziği Çalgı Bilgisi, Kültür Bakanlığı Yayınları.

Öztürk, O. M. (2016). Milli Mûsikî Ütopyası: Halk Ruhunu Garp Fenniyle Terkib Etmek İllüzyon: Cumhuriyet'in Klasik Müziğin Serüveni. (Ed. F. Kutluk), Illlüzyon: Cumhuriyet'in Klasik Müziğin Serüveni (s. 177-194). H2O Kitap.

Öztürk, O. M. (2018). Türkiye'de Halk Müziği Derleme Çalışmalarının 100 Yıllık Öyküsü. (Ed. F. Kutluk), Cumhuriyet'in Müzik Politikaları. H2O Kitap.

Parlak, E. (2000). Türkiye'de El İle (Şelpe) Bağlama Çalma Geleneği Ve Çalış Teknikleri: Kültür Bakanlığı Yayınları.

Parlak, E. (1998). Türkiye'de El İle (Tezenesiz) Bağlama Çalma Geleneği Ve Çalış Teknikleri. Yayımlanmış Sanatta Yeterlilik Tezi, İstanbul Teknik Üniversitesi, Sosyal Bilimler Enstitüsü.

Parlak, E. (2016). Cumhuriyetin Kuruluşundan Günümüze Sosyokültürel Gelişimeler Bağlamında Yöntem ve Yaklaşımlar Açısından Bağlama İcrası ve Eğitimi. (Ed. Adnan Koç), I. Uluslararası Nida Tüfekçi Bağlama Sempozyumu. İstanbul Teknik Üniversitesi Yayınları.

Nielsen, S. G., Johansen G. G., \& Jorgensen, H. (2018). Peer Learning in Instrumental Practicing . Frontiers in Psychology, 9 (339). https://doi.org/10.3389/fpsyg.2018.00339 https://doi.org/10.3389/fpsyg.2018.00339

Tuğcular, E. (1989). Bağlama ve Halk Müziği Toplulukları için Çoksesli Türküler Dăgarcı̆̆g, Kalaba Yayınlar1.

Tunalı, S. (2013 ). Halkevlerinde Yürütülen Sanat Çalışmaları (1932-1950) Sosyal Bilimler Dergisi Trakya Üniversitesi $2013 \quad 152$ 59-76. Sosyal Bilimler Dergisi, 15 (2), 59-76. https://doi.org/10.12780/uusbd180

Türkmen, U. (2007). Türk Müziğinde Çokseslilik Tartışmaları. Sosyal Bilimler Dergisi, 9(1), 177194.

Türkmen, E. F. (2010). Halk Müziğindeki Değişimler ve Halk Müziği Eğitimine Etkileri. Kuramsal Eğitimbilim Dergisi, 3(2), 53-68. 